\title{
Review \\ Pharmacogenomics Variability of Lipid-Lowering Therapies in Familial Hypercholesterolemia
}

\author{
Nagham N. Hindi ${ }^{1,+}{ }^{\dagger}$ Jamil Alenbawi ${ }^{1,+}$ and Georges Nemer ${ }^{1,2, *(1)}$ \\ 1 Division of Genomics and Translational Biomedicine, College of Health and Life Sciences, \\ Hamad Bin Khalifa University, Doha P.O. Box 34110, Qatar; nhindi@hbku.edu.qa (N.N.H.); \\ jalenbawi@hbku.edu.qa (J.A.) \\ 2 Department of Biochemistry and Molecular Genetics, Faculty of Medicine, American University of Beirut, \\ Beirut DTS-434, Lebanon \\ * Correspondence: gnemer@hbku.edu.qa; Tel.: +974-445-41330 \\ + Those authors contributed equally to the work.
}

Citation: Hindi, N.N.; Alenbawi, J.;

Nemer, G. Pharmacogenomics

Variability of Lipid-Lowering

Therapies in Familial

Hypercholesterolemia. J. Pers. Med.

2021, 11, 877. https://doi.org/

10.3390/jpm11090877

Academic Editor: Su-Jun Lee

Received: 6 August 2021

Accepted: 29 August 2021

Published: 31 August 2021

Publisher's Note: MDPI stays neutral with regard to jurisdictional claims in published maps and institutional affiliations.

Copyright: () 2021 by the authors. Licensee MDPI, Basel, Switzerland. This article is an open access article distributed under the terms and conditions of the Creative Commons Attribution (CC BY) license (https:// creativecommons.org/licenses/by/ $4.0 /)$.

\begin{abstract}
The exponential expansion of genomic data coupled with the lack of appropriate clinical categorization of the variants is posing a major challenge to conventional medications for many common and rare diseases. To narrow this gap and achieve the goals of personalized medicine, a collaborative effort should be made to characterize the genomic variants functionally and clinically with a massive global genomic sequencing of "healthy" subjects from several ethnicities. Familialbased clustered diseases with homogenous genetic backgrounds are amongst the most beneficial tools to help address this challenge. This review will discuss the diagnosis, management, and clinical monitoring of familial hypercholesterolemia patients from a wide angle to cover both the genetic mutations underlying the phenotype, and the pharmacogenomic traits unveiled by the conventional and novel therapeutic approaches. Achieving a drug-related interactive genomic map will potentially benefit populations at risk across the globe who suffer from dyslipidemia.
\end{abstract}

Keywords: familial hypercholesterolemia; pharmacogenomics; PCSK9 inhibitors; statins; ezetimibe; novel lipid-lowering therapy

\section{Introduction}

Familial hypercholesterolemia (FH) is the most common and first acquired pathology of lipoprotein metabolism to be characterized genetically and clinically [1]. It is identified by elevated levels of absolute low-density lipoprotein cholesterol (LDL-C) in the blood, early-onset of atherosclerotic cardiovascular diseases (ASCVD), fat accumulation in external tissues, and tendon and cutaneous xanthomas [2]. Globally, heterozygous FH afflicts around one in 250-500 individuals, with a more noticeable predominence in special communities, including the Christian Lebanese, French-Canadian, Finnish, and Afrikaner [3]. Medical symptoms of the severe phenotype, a homozygous FH, initiates at the early stages of childhood with a predicted incidence of one in a million. The intensity of FH complications such as coronary ostium and aortic root predominantly rely on total LDL-C levels [4,5]. Clinical examination of FH can be verified based on premature cardiovascular diseases (CVD), physical marks, and a history of raised cholesterol levels. In addition to the serum lipids analysis, various systemic diagnostic guidelines suggest cascade genomic examining to detect $\mathrm{FH}$ and confirm the polymorphisms in family members up to the third degree, including the Dutch Lipid Clinic Network-Make Early Diagnosis to Prevent Early Deaths (Dutch-MEDPED) [6]. Genetic testing could facilitate early recognition and treatment of undiagnosed, untreated FH patients and is known to provide a better prognosis of the disease.

Inherited disease-causative impairments of the low-density lipoprotein-receptor gene, (LDLR) present in $70-90 \%$ of subjects, and, less commonly, the apolipoprotein B gene 
$(A P O B)$, as well as proprotein convertase subtilin/Kexin, member nine genes (PCSK9) have been linked to raised lipoprotein cholesterol in $\mathrm{FH}(190-400 \mathrm{mg} / \mathrm{dL})$ [3]. Additional genes encoding the LDLR-adaptor protein 1 (LDLRAP1) and apolipoprotein E (APOE) can infrequently correlate with cholesterol homeostasis and promote the development of autosomal recessive $\mathrm{FH}[4] . A P O B$ and $A P O E$ genes are responsible for encoding ApoB-100 and ApoB-48 isoforms as well as ApoE, respectively, which are the elemental apolipoproteins of the LDL-C and are the protein ligands of LDLR. PCSK9 gene encodes member 9 of the PCSK family that involves the lysosomal degeneration and coordination of LDLR. The LDLRAP1 protein encoded by the LDLRAP1 gene has a phosphotyrosine binding domain that interacts and harmonizes the LDLR activity. The physiological uptake and catabolism of fats are essentially mediated by hepatic LDLR, which is encoded via the $L D L R$ gene [3,4]. Interestingly, the number of variations in $L D L R$ and associated genes related to the clinical manifestations of $\mathrm{FH}$ is uniformly rising.

For a long time, there was an apparent focus on investigating $L D L R$ variants to recognize the impact on the medical, biochemical, and pathological phenotypes of $\mathrm{FH}$ monogenic dysfunctions. It is noteworthy that the significant phenotypic diversity of lipids and coronary artery disorders depends on the nature of FH genetic defects. These defects are modulated, however, by various genetic and epigenetic factors and, thus, various pathological genotypes can differentially impact the circulating levels of LDL-C $[7,8]$. For instance, a nonsense variant in the $L D L R$ (c.2043 C >A, p. cys681X) was predominantly combined with familial hypercholesterolemia in nearly $82 \%$ of Lebanese cases. This Lebanese allele leads to a $L D L R$ loss-of-function (null) defect and attenuates hepatic metabolism and removal of LDL-C and is believed to lead to a very severe phenotype [9]. Paradoxically, the mutation is a founder mutation in the Lebanese population and was encountered in Lebanese individuals with normal cholesterol levels. This indicates the presence of unrecognized variants and/or an epigenetic signature that counters the effects of the deleterious LDLR mutation in these cases [10]. Consequently, genetic diagnostic screening of disease-causative mutations, considered the gold standard for FH detection, is not enough, but should be coupled with whole-genome sequencing and/or methylation analysis to further stratify affected members within familial cases.

Despite the prevalence of $\mathrm{FH}$ and the significance of early determination and management of the condition, only $15-20 \%$ of $\mathrm{FH}$ subjects are diagnosed by medical examination. Untreated patients with heterozygous $\mathrm{FH}$ have a nearly 20 -fold higher raised incidence of premature coronary artery disease relative to cases without FH [11]. Coronary artery disease and heart attacks restrict coronary blood flow, causing the pumping chamber to enlarge, widen, and attenuate. Ultimately, this damage will lead to ischemic cardiomyopathy, potentially reducing the ability of cardiomyocytes to pump blood [12]. The earliest clinical mark of the disease regularly happens throughout the third decade of growth, particularly in severe cases with LDLR-negative mutational status, such as fatal myocardial infarction [5]. Appropriate identification and management could control the lipid levels and limit the life-threatening complications of FH. A current examination documented that early introduction of lipid-lowering medicine throughout childhood and adolescents in cases with FH can ameliorate the pathological progression and reduce the incidence of ASCVD, explaining the considerable advantage of immediate FH treatment [13]. Numerous studies have revealed that only $10 \%$ reached the recommended cholesterol levels even though most patients receive the maximum tolerated cholesterol-modulating drugs [14].

The pharmacological variation among FH patients has been linked to the genomic single nucleotide polymorphisms (SNPs) of genes associated with cholesterol catabolism and biosynthesis [15]. In extreme cases of FH, genetic screening could potentially be used to examine the response variability and, therefore, to effectively personalize the therapeutic care plan for the anti-lipid interventions and CVD risk preventions. Under this scenario, this review will discuss the management of familial hypercholesterolemia with the standard and innovative therapeutic strategies from the prospect of pharmacogenomics and its link to the causative genetic mutations underlying the phenotype. 


\section{FH Management}

The main goal of FH therapy is to reduce relative LDL-C by more than $50 \%$ or to lower LDL-C to $100 \mathrm{mg} / \mathrm{dL}$ in adults without ASCVD. For FH subjects with ASCVD or major CVD risk, the $2019 \mathrm{ESC} / \mathrm{EAS}$ guidelines recommend a more than $50 \%$ reduction of LDL-C or less than $55 \mathrm{mg} / \mathrm{dL}$ of absolute LDL-C [6]. Therapeutic lifestyle modifications such as restricted diet, regular physical training, limiting alcohol intake, and smoking cessation are all fundamental in the controlling of FH [16]. In addition, patients should be counseled to maintain healthy blood sugar, blood pressure, and weight. Despite the paramount importance of non-pharmacological management in all $\mathrm{FH}$ patients, optimizing cholesterol levels and preventing CVD are hardly achieved without pharmacological interventions [5].

Currently, $\beta$-hydroxy- $\beta$-methylglutaryl coenzyme A reductase (HMGCR) inhibitors at the highest tolerable dose are strongly recommended to be initiated immediately at diagnosis in all FH adults. Monotherapy, daily doses of the aggressive statins, and HMGCR inhibitors, including atorvastatin $40-80 \mathrm{mg}$ and rosuvastatin $20-40 \mathrm{mg}$ orally per day, are expected to decrease LDL-C approximately $50-60 \%$, as reported in various cholesterollowering studies $[11,14]$. When the target fails to be achieved, stepwise intensification of anti-lipid medications should be considered. Ezetimibe, a cholesterol uptake blocker, can decrease the LDL-C by nearly $25 \%$ and is recommended as an adjunctive second-line treatment $[6,11]$.

PCSK9-based medications are a great breakthrough in FH pharmacotherapy, with a reduction in LDL-C ranging from $25 \%$ to $30 \%$. The anti-PCSK9 monoclonal antibodies, evolocumab and alirocumab, should be initiated if maximum intense statins and ezetimibe fail to sufficiently control the lipid profile in FH cases with a major risk of cardiomyopathies [6]. In 2013, the Food and Drug Administration (FDA) approved using a microsomal triglyceride transfer (MTP) inhibitor, lomitapide, and an oligonucleotide agent, mipomersen, as add-on medications to the classic anti-lipids in adults with the severe $\mathrm{FH}$ phenotype. Lipoprotein apheresis should be offered for individuals with either homozygous $\mathrm{FH}$ or severe-uncontrolled heterozygous $\mathrm{FH}$, which may reduce $60-80 \%$ of LDL-C [6]. The cholesterol metabolism pathway and pharmacological targets for classical and novel lipid-lowering therapies are schematically summarized in Figure 1.

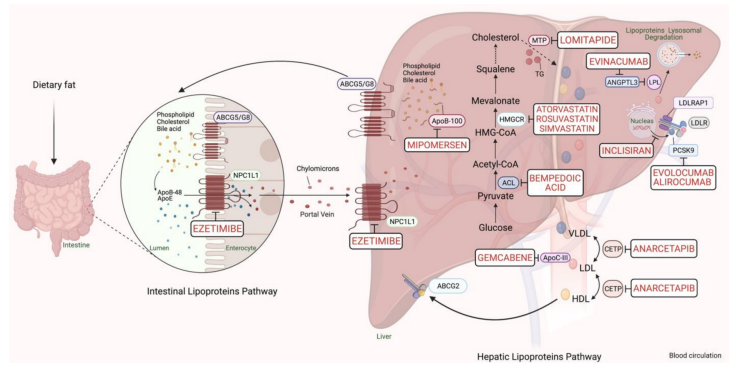

Figure 1. Scheme representing the cholesterol metabolism pathway and pharmacological targets for classical and novel lipid-lowering therapies (generated with BioRender.com). Unique hepatic and intestinal transporters (ABCG5 and ABCG8) release bile acids, phospholipids, and cholesterol into the biliary system. Inversely, the NPC1L1 protein modulates cholesterol returning to hepatocytes. Ezetimibe inhibits cholesterol entry into the intestine and liver by the NPC1L1 transporter. Next, chylomicrons are generated through the assembly of TG, cholesterol, and ApoB-48, and released into the blood circulation (see intestinal lipoproteins pathway). The speed-limiting enzyme of endogenous cholesterol synthesis, HMGCR (see hepatic lipoproteins pathway), is inhibited via statins. The activated bempedoic acid decreases the hepatic synthesis of acetyl CoA and cholesterol catabolism by blocking the ACL protein. ApoB-100, phospholipid, ApoC-III, and cholesterol assembly into VLDL depends on the activity of MTP, which is blocked by lomitapide. The degradation of hepatic messenger ribonucleic acid (mRNA) transcript of ApoB-100 and ApoC-III is mediated by mipomersen and gemcabene, respectively. The heteroexchange of TGs and cholesteryl esters between ApoB-lipoproteins particles relies on CETP activity, which is blocked by CETP inhibitors such as anacetrapib. 
LDLR interacts and removes LDL-cholesterol from the blood circulation with the assistance of LDLRAP1. Lysosomal catabolism of LDLR is mediated by PCSK9. Anti-PCSK9 antibodies, including evolocumab, alirocumab, and inclisiran inhibit the endogenous production and release of PCSK9. Evinacumab blocks the inhibition of hepatic lipoprotein lipase activity by ANGPTL3. Abbreviations: ApoB-48/100, Apolipoprotein B protein member 48 \& 100; ApoC-III, Apolipoprotein C protein, member III; ApoE, Apolipoprotein E protein; HDL, High-density lipoprotein cholesterol; LDL, lowdensity lipoprotein; VLDL, very-low-density lipoprotein; TG, triglyceride; LDLR, LDL-receptor; LDLRAP1, LDLR-adaptor protein, member 1; ABCG2, atp-binding cassette, subfamily g, member 2; HMGCR, $\beta$-hydroxy- $\beta$-methylglutaryl Coenzyme A Reductase; NPC1L1, Niemann-Pick C1-like 1 transporter protein; ACL, adenosine triphosphate citrate lyase; MTP, microsomal triglyceride transfer protein; LPL, lipoprotein lipase; CETP, cholesteryl ester transfer protein; ANGPTL3, angiopoietin-like protein 3; PCSK9, proprotein convertase subtilin/kexin 9 protein.

For familial genotyped cases, the current therapeutic protocols suggest maintaining LDL-C below $135 \mathrm{mg} / \mathrm{dL}$ for children aged 10 or older and reducing LDL-C by $50 \%$ for younger ages. A healthy lifestyle could achieve this goal in conjugation with a mild statin regimen, subject to dosage increase, to reach the targeted-cholesterol levels $[6,16]$. Nevertheless, various FH cases are still not controlled despite aggressive therapeutic interventions. Contemporary information from the International Pediatric FH Register revealed that $23 \%$ of heterozygous FH children on statins had not reached the targeted LDL-C goal (below $135 \mathrm{mg} / \mathrm{dL}$ ) [17].

The wide variation of cholesterol-lowering therapies in terms of the potential adverse effect and therapeutic response is one of the main challenges in clinical practice, especially in $\mathrm{FH}$ patients. In addition to clinical and environmental factors, including race, gender, age, smoking, and adverse consequences, genomic phenotypes of $L D L R$, $A P O B$, and PCSK9 can potentially modulate the sensitivity of anti-lipids. Over the previous decade, many pharmacogenomics and genome-wide association studies (GWASs) have recognized numerous genetic variations that can affect the therapeutic potency (anti-lipid pharmacodynamics), drug absorption, metabolism, excretion (anti-lipid pharmacokinetics), and anti-lipid toxicity pathways $[3,18]$. Accordingly, therapeutic efficiency and safety and patient quality of life could be promoted through personalized genomic examination, which is designed to predict the therapeutic response of FH management.

\section{Pharmacogenomics of Statin in FH}

The primary and secondary prevention of CVD and the cornerstone medication in patients with FH are via HMGCR inhibitors [5,6]. Statins could potentially decrease the plasma levels of atherosclerotic LDL-C via competitively inhibiting the HMGCR (Figure 1) [11]. The inhibition of this protein reduces the hepatic synthesis of cholesterol and, thereby, enhances LDLR production. Subsequently, the elevated expression of LDLR on the hepatocytic membrane will increase the cellular uptake of cholesterol from the bloodstream, mainly by the liver. Furthermore, the secretion of ApoB-containing lipoproteins, LDL, and very-low-density lipoprotein (VLDL), as well as triglycerides from hepatocytes, may also be lowered via statins [11]. The lifelong overburden of high cholesterol makes patients with FH highly susceptible to the risk of CVD and significantly reduces their life expectancy [2]. Although statins robustly diminish cholesterol in addition to CVD morbidity and mortality by $20-30 \%$ in normal individuals, their efficacy is predominantly weaker in FH subjects [5]. Genetic variations combined with non-adherence due to statin myotoxicity or hepatotoxicity may cause pharmacological variability among patients. We will divide the variants according to the effect they have on either the pharmacodynamics or the pharmacokinetics of these drugs.

\subsection{SNPs Linked to Pharmacodynamics of Statins in FH}

The hepatocyte endocytosis of lipoproteins is mediated mainly by LDLR in addition to other processing associated proteins, including PCSK9, APOE, and LDLRAP1. SNPs in the $L D L R$ could selectively reshape the anti-lipids therapeutic outcome and the incidence 
of FH and coronary artery conditions. Therefore, the pharmacogenetic analysis principally concentrates on discovering these mutations, as reviewed in Table 1 [19-24]. Polisecki and colleagues observed a strong association between the serum-baseline cholesterols and statin efficacy in terms of coronary artery disease risk in FH patients carrying an LDLR polymorphism (rs1433099, c.44857C >T) [25]. The 3'-untranslated region (3'-UTR) of LDLR has been found to play a basic role in the anti-lipids mediated-LDL-C reduction through stabilizing the LDLR mRNA. Polymorphisms at the 3-UTR loci have been linked to lipid baselines, LDLR activity, and CVD [26]. Interestingly, subjects with mixed LDLR and HMGCR haplotypes have more prominent attenuations in optimizing desired cholesterols than those carrying a single $L D L R$ mutation [27]. The cholesterol-lowering potency of pravastatin has also been modulated by another LDLR genetic defect (rs5925, c.2052T>C) [28]. Recently, LDLR stop-gained pathogenic variants (c.2027delG, p. Gly676Alafs*33) have been discovered to be correlated with anti-lipid efficacies including statins, ezetimibe, and clinical manifestations of FH [29].

Several investigations have noticed that the physiological effect of lipid-modifying drugs, especially statin, and the lipid profile in heterozygous FH subjects is affected by the presence of LDLR variants and the type of mutation. Individuals carrying a null mutation (deletions result in a frameshift and premature stop codon) were observed to have diminished LDL-C responses with elevated cholesterols compared to patients carrying a defective (non-frameshift small insertions or deletions) or without mutation [30-34].

Table 1. Pharmacogenomics variations associated with statin response in familial hypercholesterolemia patients.

\begin{tabular}{|c|c|c|c|c|c|c|c|}
\hline Gene & Significant Mutation * & Patients & Population & Sample Size & $\begin{array}{l}\text { Treatment and } \\
\text { Daily Dose }\end{array}$ & Clinical Findings & $\begin{array}{l}\text { Author, Year } \\
\text { (References) }\end{array}$ \\
\hline LDLR & $\begin{array}{l}\text { FH1 (C206G) \& } \\
\text { FH2 (G408A) }\end{array}$ & Het-FH & Afrikaners & 20 & Simvastatin $40 \mathrm{mg}$ & $\begin{array}{l}\text { TC reduction is higher in patients with FH2 } \\
\text { than FH1 }\end{array}$ & Jeenah et al., 1993 [19] \\
\hline$L D L R$ & $\begin{array}{l}\text { C660X, D147H, \& } \\
\text { 652delGGT }\end{array}$ & Het-FH & Israeli & 64 & Fluvastatin $40 \mathrm{mg}$ & $\begin{array}{l}\text { Reduction of LDL-C, apoA, and elevation } \\
\text { of HDL-C depend variously on } \\
\text { LDLR mutations }\end{array}$ & $\begin{array}{l}\text { Leitersdorf et al., } \\
\quad 1993[23]\end{array}$ \\
\hline$A P O E$ & E2,3, \& 4 alleles & Het-FH & Canadian & 49 & Lovastatin $80 \mathrm{mg}$ & $\begin{array}{l}\text { Statin sensitive is higher in men with } \mathrm{E} 4 \\
\text { than E3 or } \mathrm{E} 2 \text { or women with any } \\
\text { APOE phenotype }\end{array}$ & Carmena et al., 1993 [35] \\
\hline$L D L R$ & $\begin{array}{c}\mathrm{FH}_{\text {TONAMI-1 }}(\mathrm{Del} \\
\text { exon15) } \\
\& \mathrm{FH}_{\text {KANAZAWA }} \\
(\mathrm{C} 665 \mathrm{~T}) \\
\end{array}$ & Het-FH & Japanese & 12 & $\begin{array}{l}\text { Pravastatin \& } \\
\text { cholestyramine }\end{array}$ & $\begin{array}{l}\text { LDL-C reduction is higher in patients with } \\
\text { FH }_{\text {KANAZAWA than FH1 FH TONAMI-1 }}\end{array}$ & Kajinami et al., 1998 [20] \\
\hline$L D L R$ & $\begin{array}{l}\text { W66G, } \mathrm{C} 646 \mathrm{Y}, \& \mathrm{c} \\
\text { deletion>15 kb }\end{array}$ & Het-FH & Canadian & 63 & Simvastatin $20 \mathrm{mg}$ & $\begin{array}{l}\text { LDL-C reduction is higher in patients with } \\
\text { C } 646 \mathrm{Y} \text { \& deletion }>15 \mathrm{~kb} \text { than W66G }\end{array}$ & Couture et al., 1998 [21] \\
\hline LDLR & Severe and mild LDLR & Het-FH & British & 42 & $\begin{array}{c}\text { Simvastatin }+ \text { bile } \\
\text { acid sequestrant }\end{array}$ & $\begin{array}{l}\text { LDL-C is higher in patients with severe } \\
\text { than mild mutation }\end{array}$ & Sun et al., (1998) [33] \\
\hline$L D L R$ & $\begin{array}{l}\text { Null and defective } \\
\text { LDLR }\end{array}$ & Het-FH & British & 109 & Simvastatin & $\begin{array}{l}\text { LDL-C reduction is higher in patients with } \\
\text { defective than null mutation }\end{array}$ & Heath et al., (1999) [31] \\
\hline$L D L R$ & $\begin{array}{c}\text { AvalI (rs5925T }>C) \\
\text { HincII (rs688C }>\mathrm{T}), \& \\
\text { PvuII (rs2569542A }>\text { G) }\end{array}$ & Het-FH & Brazilian & 55 & Fluvastatin $40-80 \mathrm{mg}$ & $\begin{array}{l}\text { LDL-C, TC, \& ApoB reduction is higher in } \\
\text { patients with AvaII \& PvuII than HincII }\end{array}$ & Salazar et al., 2000 [22] \\
\hline$L D L R$ & $\begin{array}{l}\text { Null and defective } \\
L D L R\end{array}$ & $\mathrm{FH}$ & Spanish & 55 & Simvastatin $20 \mathrm{mg}$ & $\begin{array}{l}\text { Low HDL-C \& poor statin response are } \\
\text { higher in patients with defective than } \\
\text { null mutations }\end{array}$ & Chaves et al., (2001) [32] \\
\hline$A P O E$ & E4 allele & Het-FH & British & 19 & $\begin{array}{l}\text { Atorvastatin } 10 \mathrm{mg}+ \\
\text { bile acid sequestrant }\end{array}$ & $\begin{array}{l}\text { Poor statins response is high in patients } \\
\text { with E4 phenotype }\end{array}$ & O'Neill et al., 2001 [36] \\
\hline LDLR & $\begin{array}{l}\text { Null and defective } \\
L D L R\end{array}$ & Het-FH & Canadian & 63 & Atorvastatin $20 \mathrm{mg}$ & $\begin{array}{l}\text { LDL-C reduction is higher in patients with } \\
\text { null than defective mutation }\end{array}$ & Vohl et al., (2002) [37] \\
\hline$L D L R$ & $\begin{array}{l}\text { G1775A, } \\
\text { G1646A, \& C858A }\end{array}$ & Het-FH & Greek & 49 & Atorvastatin $20 \mathrm{mg}$ & $\begin{array}{l}\text { LDL-C \& ApoB reduction is higher in } \\
\text { patients with G1775A than G1646A } \\
\qquad \& \text { C858A }\end{array}$ & $\begin{array}{l}\text { Miltiadous et al., } \\
2005[24]\end{array}$ \\
\hline MTP & c.493 GT & Het-FH & Spanish & 222 & Atorvastatin $20 \mathrm{mg}$ & $\begin{array}{l}\text { High reduction of TG in men and low } \\
\text { reduction of VLDL \& TG in women with } \\
\text { c.493 GT allele }\end{array}$ & $\begin{array}{l}\text { García-Garc ía et al., } \\
\quad 2005[38]\end{array}$ \\
\hline CETP & -867 and Ex14/I405V & & & & & & \\
\hline MDR1 & $\begin{array}{l}\text { c. (G2677T) and } \\
\text { c.(C3435T) }\end{array}$ & Het-FH & Israeli & 76 & Fluvastatin $40 \mathrm{mg}$ & $\begin{array}{l}\text { LDL-C reduction is high among CETP \& } \\
\text { MDR1 mutants }\end{array}$ & $\begin{array}{l}\text { Bercovich et al., } \\
2006[39]\end{array}$ \\
\hline$L D L R$ & $\begin{array}{l}\text { Null and defective } \\
L D L R\end{array}$ & Het-FH & Spanish & 811 & $\begin{array}{c}\text { Simvastatin or } \\
\text { atorvastatin } 80 \mathrm{mg} \pm \\
\text { bile acid sequestrant }\end{array}$ & $\begin{array}{l}\text { PCVD \& TC is higher in patients with null } \\
\text { than defective mutations }\end{array}$ & Alonso et al., 2008 [40] \\
\hline ABCG2 & rs2231142 & $\mathrm{FH}$ & Chinese & 386 & Rosuvastatin $10 \mathrm{mg}$ & $\begin{array}{l}\text { High LDL-C reduction among patients with } \\
\text { AA genotype }\end{array}$ & Hu et al., $2010[41]$ \\
\hline$L D L R$ & $\begin{array}{l}\text { Null and defective } \\
L D L R\end{array}$ & $\mathrm{FH}$ & Spanish & 387 & $\begin{array}{l}\text { Maximum statin doses } \\
* *+\text { ezetimibe } 10 \mathrm{mg}\end{array}$ & $\begin{array}{l}\text { Poor LLT response \& high PCVD in } \\
\text { patients with null than defective mutations }\end{array}$ & Mata et al. (2011) [42] \\
\hline LDLR & W556R & $\begin{array}{l}\text { Twins with } \\
\text { Hom-FH and } \\
\text { parents with } \\
\text { Het-FH (one } \\
\text { family) }\end{array}$ & Turkish & 4 & $\begin{array}{l}\text { Simvastatin } 40 \mathrm{mg}+ \\
\text { ezetimibe } 10 \mathrm{mg} \text { or } \\
\text { LDL apheresi }\end{array}$ & $\begin{array}{l}\text { Hom-FH have a low LDL-C reduction and } \\
\text { high statin resistance, but Het-FH respond } \\
\text { to statin with } 60 \% \text { LDL-C reduction }\end{array}$ & Schaefer et al., 2012 [43] \\
\hline
\end{tabular}


Table 1. Cont.

\begin{tabular}{|c|c|c|c|c|c|c|c|}
\hline Gene & Significant Mutation * & Patients & Population & Sample Size & $\begin{array}{l}\text { Treatment and } \\
\text { Daily Dose }\end{array}$ & Clinical Findings & $\begin{array}{l}\text { Author, Year } \\
\text { (References) }\end{array}$ \\
\hline СУРЗАА & rs2740574 & $\mathrm{FH}$ & Chilean & 142 & Atorvastatin $10 \mathrm{mg}$ & $\begin{array}{l}\text { High statin sensitivity among patients with } \\
\text { CYP3A4 mutations }\end{array}$ & Rosales et al., 2012 [44] \\
\hline ANRIL & rs1333049 & FH with CVD & Pakistani & 611 & $\begin{array}{l}\text { Atorvastatin } 10,20 \text { or } \\
40 \mathrm{mg}\end{array}$ & $\begin{array}{l}\text { High LDL-C, TC, \& TG reduction in } \\
\text { patients with CC genotype }\end{array}$ & Ahmed et al., 2013 [45] \\
\hline$L D L R$ & $\begin{array}{l}\text { Null (W66G) and } \\
\text { defective (C646Y) LDLR }\end{array}$ & Het-FH & Brazilian & 156 & $\begin{array}{l}\text { Atorvastatin 10, } 20 \text { or } \\
40 \mathrm{mg}\end{array}$ & $\begin{array}{l}\text { LDL-C reduction is more in patients with } \\
\text { defective than with null mutation }\end{array}$ & Santos et al., 2014 [30] \\
\hline POR & rs1057868 & FH & Greek & 105 & $\begin{array}{l}\text { Atorvastatin } 10,20 \text { and } \\
40 \mathrm{mg}\end{array}$ & $\begin{array}{l}\text { High LDL-C \& TC reduction in patients } \\
\text { with } 1 / 1 \text { genotype }\end{array}$ & Drogari et al., 2014 [46] \\
\hline$M Y L I P$ & rs9370867 & Het-FH & Brazilian & 156 & $\begin{array}{l}\text { Atorvastatin } 10-80 \mathrm{mg} \\
\pm \text { ezetimibe } 10 \mathrm{mg}\end{array}$ & $\begin{array}{l}\text { High LDL-C reduction in patients with } \\
\text { AA genotype }\end{array}$ & Santos et al., 2014 [47] \\
\hline РSCK9 & E32K & \multirow{2}{*}{ Hom-FH } & \multirow{2}{*}{ Japanese } & \multirow{2}{*}{1055} & \multirow{2}{*}{$\begin{array}{l}\text { Atorvastatin } 80 \mathrm{mg} \& \\
\text { ezetimibe } 10 \mathrm{mg}\end{array}$} & \multirow{2}{*}{$\begin{array}{c}\text { PSCK9 gain-of-function variants } \\
\text { significantly worsen } L D L R \text { phenotype and } \\
\text { decrease LDL-C reduction }\end{array}$} & \multirow{2}{*}{$\begin{array}{l}\text { Mabuchi, et al., } \\
\quad 2014[48]\end{array}$} \\
\hline$L D L R$ & Double allele & & & & & & \\
\hline$L D L R$ & $\begin{array}{l}\text { Null and defective } \\
\text { LDLR }\end{array}$ & $\mathrm{FH}$ & Spanish & 4132 & $\begin{array}{l}\text { Maximum statin doses } \\
* *+\text { ezetimibe } 10 \mathrm{mg}\end{array}$ & $\begin{array}{l}\text { Poor LLT response \& CVD events are } \\
\text { higher in null than in defective mutation }\end{array}$ & $\begin{array}{l}\text { Perez de Isla et al., } \\
2016[14]\end{array}$ \\
\hline LDLR & p.(Cys155Gly) & Hom-FH & Belgian & 8 & $\begin{array}{l}\text { Atorvastatin } 80 \mathrm{mg} \text {, } \\
\text { ezetimibe } 10 \mathrm{mg} \text {, } \\
\text { cholestyramine }\end{array}$ & $\begin{array}{l}\text { LLT efficacy is attenuated in patients with } \\
\text { nonsense } L D L R \text { mutations }\end{array}$ & Sanna et al., 2016 [34] \\
\hline HMGCR & rs3846662 & Het-FH & French Canadian & 106 & Statin + LLT $\Omega$ & $\begin{array}{l}\text { Poor statin response among } \\
\text { HMGCR mutants }\end{array}$ & Leduc et al., 2016 [49] \\
\hline$L D L R$ & $\begin{array}{c}\text { W87G, C368Y, T726I, } \\
\text { G2fsX214, D47N, N97H, } \\
\text { E101K, C216fsX, L582P, } \\
\text { C667Y, \& LDLR-17-18 } \\
\text { del }\end{array}$ & \multirow[t]{2}{*}{ Het-FH } & \multirow[t]{2}{*}{$\begin{array}{l}\text { American and } \\
\text { Canadian }\end{array}$} & \multirow[t]{2}{*}{139} & \multirow[t]{2}{*}{$\begin{array}{c}\text { Atorvastatin } 40 / 80 \mathrm{mg} \text {, } \\
\text { rosuvastatin } 20 / 40 \mathrm{mg} \\
\text { or simvastatin } \\
40 / 80 \mathrm{mg},+ \\
\text { Bococizumab } 0.25,1,3, \\
\text { or } 6 \mathrm{mg} / \mathrm{kg}\end{array}$} & \multirow[t]{2}{*}{$\begin{array}{c}\text { Bococizumab effecacy is higher than statin } \\
\text { in reducing LDL-C across } L D L R \& \\
\text { APOB variants }\end{array}$} & \multirow[t]{2}{*}{ Fazio et al., 2018 [50] } \\
\hline$A P O B$ & R3527Q & & & & & & \\
\hline$L D L R$ & Het-LDLR mutation & \multirow{2}{*}{$\mathrm{FH}$} & \multirow{2}{*}{ Spanish } & \multirow{2}{*}{22} & \multirow{2}{*}{$\begin{array}{l}\text { Maximum statin doses } \\
* * \pm \text { ezetimibe } 10 \mathrm{mg}\end{array}$} & \multirow{2}{*}{$\begin{array}{l}\text { LDL-C reduction is higher in patients with } \\
\text { p.(Leu167del) mutation than LDLR }\end{array}$} & \multirow{2}{*}{ Bea et al., 2019 [51] } \\
\hline$A P O E$ & p.(Leu167del) & & & & & & \\
\hline $\begin{array}{l}\text { LDLR } \\
\text { SLCO1B1 } \\
\text { ABCB11 } \\
\text { CYP3A5 }\end{array}$ & $\begin{array}{c}r \mathrm{~s} 28941776 \\
\text { c. }\left(521 \mathrm{~T}>\mathrm{C} ; \mathrm{SLCO} 1 \mathrm{~B} 11^{* 5}\right) \\
\& \mathrm{c} .(388 \mathrm{~A}>\mathrm{G} ; \\
\mathrm{SLCO1B1} * 1 \mathrm{~B}) \\
\text { rs228722 } \\
\text { CYP3A } 5 * 3\end{array}$ & $\mathrm{FH}$ & Caucasian & 1 & $\begin{array}{l}\text { Rosuvastatin } 40 \mathrm{mg} \& \\
\text { ezetimibe } 10 \mathrm{mg}\end{array}$ & $\begin{array}{l}\text { Loss-of-function mutations enhance statin } \\
\text { myotoxicity and delay its response }\end{array}$ & $\begin{array}{c}\text { Dagli-Hernandez et al., } \\
2021[52]\end{array}$ \\
\hline$L D L R$ & $\begin{array}{l}\text { c.(2027delG), p. } \\
\text { (Gly676Alafs*33) }\end{array}$ & FH (2 families) & Saudi & 12 & Statin + ezetimibe & $\begin{array}{l}\text { Clinical manifestations and poor LLT } \\
\text { response depend on LDLR variants }\end{array}$ & Awan et al., 2021 [29] \\
\hline
\end{tabular}

${ }^{*}$ Borderline significance $(p<0.05) .{ }^{* *}$ Maximum tolerated dose of statin: simvastatin $80 \mathrm{mg}$, pravastatin $40 \mathrm{mg}$, lovastatin $80 \mathrm{mg}$, fluvastatin $80 \mathrm{mg}$, atorvastatin $80 \mathrm{mg}$, or rosuvastatin 20-40 mg. $\Omega$ LLT including ezetimibe, fibrates, statins, lomitapide, PCSK9 inhibitors, bile acid sequestrants (e.g., cholestyramine and colestipol), or niacin. Abbreviations: LLT; lipid-lowering therapies; PCVD, premature cardiovascular diseases; FH, familial hypercholesterolemia; Het-FH, patients with heterozygous FH; Hom-FH, patients with homozygous FH; ApoB, Apolipoprotein B protein; HDL-C, High-density lipoprotein cholesterol; LDL-C, low-density lipoprotein cholesterol; TC, total cholesterol; TG, triglyceride; $L D L R$, Low-density lipoprotein receptor; $A P O B$, Apolipoprotein B; $A B C G 2$, atp-binding cassette, subfamily g, member 2; MDR1, multidrug resistance mutation 1; CYP3A4, Cytochrome P450, family 3, subfamily A, member 4; ANRIL, antisense non-coding RNA in the INK4 locus; POR, Cytochrome P450 Oxidoreductase; MYLIP, Myosin Regulatory Light Chain Interacting Protein; HMGCR, $\beta$-hydroxy- $\beta$-methylglutaryl Coenzyme A Reductase; E, Epsilon; SLCO1B1, solute carrier organic anion transporter $1 \mathrm{~B} 1$.

In addition, $\mathrm{FH}$ patients with a null mutation in the LDLR gene were identified as having a higher prevalence of CVD than those with a defective mutation $[14,40,42,53]$. Although these individuals at major risk of CVD are on aggressive anti-lipid regimens, most of them did not achieve the therapeutic goals of LDL-C [37,42]. On the contrary, a study by Vohl and colleagues found that the proportion of patients who achieved LDL-C targets was higher in the null mutants than in the defective mutants [37]. Schaefer et al. have confirmed that LDLR p.W556R SNP in homozygote FH patients lead to HMGCR blockers resistance but can obtain a $15 \%$ decrease of LDL-C by ezetimibe treatment. Conversely, the same $L D L R$ mutation in patients with heterozygote $\mathrm{FH}$ can decrease $60 \%$ of cholesterols under a combination of ezetimibe and simvastatin [43]. These outcomes suggest that altering the $L D L R$ should be a new pharmacological target in controlling FH.

Pharmacogenomic assays have shown that low-activity variants of $H M G C R$, which encode the cholesterol synthesis speed-limiting factor, can restrict the therapeutic potency of HMGCR blockers depending on the patients' gender. For instance, the HMGCR polymorphism, rs3846662, selectively modulates women's sensitivity to statin treatments [49]. Variations in the encoding genes of ApoA molecules and lipoprotein (A) (LPA), have been believed to constrain LDL-C response to statins and intensify coronary artery disorders [54]. Several GWAS studies have proved an association between PCSK9 polymorphisms and statin efficacy. The rs17111584 C allele in PCSK9 decreased the rosuvastatin efficacy [55], while the rs11599147 polymorphism was linked to elevated anti-lipid response [56]. A polymorphism in the WD repeat domain 52 (WDR52, rs13064411A $>$ G) can indirectly reduce 
the LDLR response to statins. This mutation is associated with statin-induced elevation of PCSK9 levels that accelerate the degradation of LDLR, resulting in elevated total cholesterol levels [57]. The myosin regulatory light chain interaction protein (MYLIP) is responsible for regulating the LDLR function in cellular lipid uptake. A study noted that heterozygous FH patients with the MYLIP rs9370867 allele respond differently to statin therapy with ezetimibe based on the mutation type. After a year of treatment, the recommended cholesterol levels could be achieved in FH patients with no mutations but not in those with defective and null phenotypes [47]. All in all, the results from various studies point out to an essential role for the LDLR mutation type in predicting response to statins but also to a preponderant role to genes involved in LDLR regulation as potential modifiers to this response.

\subsection{SNPs Linked to Pharmacokinetics and Pharmacotoxicity of Statins in FH}

Gene polymorphisms associated with pharmacokinetic and toxicokinetic may greatly contribute to the attenuated response to HMGCR inhibitors. Figure 2 reviews candidate pharmacokinetic modulator genes involved in the distribution, metabolism, and elimination of anti-lipids. The hepatic absorption of statins is mediated primarily by the solute carrier organic anion transporter 1B1 (encoded via SLCO1B1). Loss-of-function SLCO1B1*5 (c.521T>C) and SLCO1B1*1B (c.388A>G) SNPs remarkably diminish plasma LDL-C transporting to the liver and raise the systemic exposure to statin [52]. This results in a greater incidence of rhabdomyolysis risk and a negligible cholesterol optimizing effect. However, many genomic examinations have failed to connect polymorphisms in SLCO1B1 and statin-mediated cholesterol modifying effect or myotoxicity $[46,58,59]$. Mutations in the ATP-binding cassette transmembrane mediator $(\mathrm{ABC})$ have been significantly correlated with impaired efflux of statins as well as cholesterols from cells. The attenuated activity of $A B C A 1, A B C A 11$, and $A B C G 2$ was found to reduce the excretion of statin and increase its intrahepatic levels, thereby increasing hepatotoxicity as well as myopathy to statin adverse consequences [41,52].

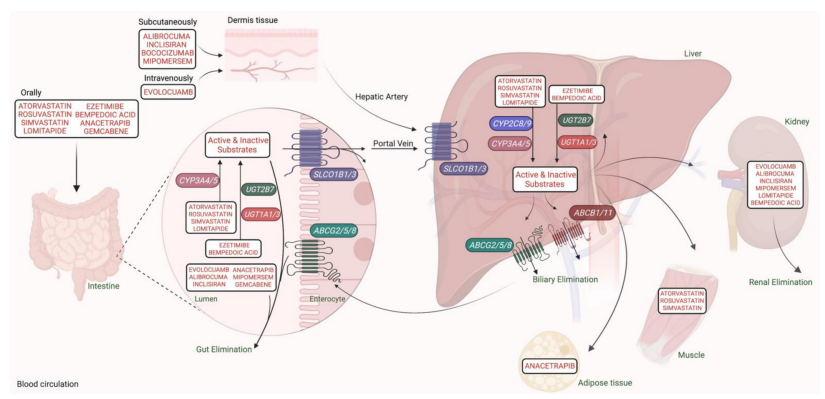

Figure 2. A schematic representation of the pharmacokinetic modulator genes involved in absorption, distribution, metabolism, and clearance of lipid-lowering therapy (created with BioRender.com). Oral lipid-antagonists enter the circulatory system via the enteric SLC and ABC gene-transporters. While intravenous anti-lipids enter directly into the circulation and reach the liver, the agents administrated subcutaneously are slowly absorbed through the blood capillaries. The liver and kidneys are the major metabolic sites for lipid-lowering medicines. The main catalytic proteins involved in their metabolic pathway are CYP and UGT, which inactivate or activate drugs. Members of the $\mathrm{ABC}$ family then mediate their elimination through kidneys, biliary, or intestinal pathways. Some drugs accumulate for a long-time in the muscle or adipose tissue. Abbreviations: ABCG2/5/8, atp-binding cassette, subfamily g, member 2, 5, or 8; SLCO1B1, solute carrier organic anion transporter 1B1; CYP3A4, Cytochrome P450, family 3, subfamily A, member 4; UGT2B7, uridine 5'-diphosphate (UDP)-glucuronosyltransferase 2B7; UGT1A1/3, uridine 5'-diphosphate (UDP)-glucuronosyltransferase $1 \mathrm{~A} 1$ or 3.

Polymorphisms of the $A P O E$ gene $(E 2, E 3$, and $E 4)$ in humans have diverse effects on removing apolipoproteins from circulation. Inhibition of the HMGCR enzyme is most 
evident in lipoproteins with the APOE4 allele, which is very efficiently removed from the blood. Various clinical trials have identified that $A P O E 4$ variants are often accompanied by elevated fats absorption, enhancing the endogenous cholesterol catabolism. Consequently, these variations may alleviate the modulation of atherogenic LDL-C in response to HMGCR inhibitors [36]. Accordingly, patients should be counseled to sustain a healthy diet or combine statins with absorption inhibitors. On the other hand, patients carrying the $E 2$ isoform and the APOE (p. Leu167del) mutation respond more efficiently to the conventional anti-lipid therapy, consistent with the poor plasma clearance that enhances the HMGCR synthesis $[35,36,51]$. Generally, APOE variations are not directly targeting the statin pharmacokinetic pathway. However, they are affecting the expression of plasma lipids and thus altering the pharmacodynamic responses of statins.

Variations of cytochrome P450 (CYP450) may exceedingly impact anti-lipids metabolism and, thus, result in a diversity of LDL-C response and adverse consequences among $\mathrm{FH}$ patients. The byproduct of these enzymes has a principal role in inhibiting the HMGR protein, indirectly promoting statin effectiveness. Therefore, nonfunctional CYP3A5*3 mutations were reported to lower the rosuvastatin efficacy in decreasing the LDL-C [52]. On the contrary, Rosales et al. have reported that CYP3A4 polymorphism rs2740574 ($290 \mathrm{~A}>\mathrm{G}$ ) enhances atorvastatin therapeutic response in subjects with FH [44]. The activity of CYP3A is chiefly controlled through the electron transferring function of cytochrome P450 oxidoreductase (POR) from NADPH. POR 28 rs1057868C $>$ T SNP has been combined with raised functionality of $C Y P 3 A$ in the $\mathrm{FH}$ cohort, explaining the diverse therapeutic responses to statin [46]. Nonetheless, many studies found that mutations in CYP450 genes are not linked to anti-lipids intolerance [44].

Hepatic metabolism of various compounds, including statins, can be mediated through the metabolic function of $\mathrm{N}$-acetyltransferase type 2 (NAT2). A mutation in this enzyme can either enhance or delay physiological metabolism. A considerable variation in the statin pharmacokinetics was reported in NAT2-rs1208 polymorphism carriers [60]. Interestingly, a wide pharmacogenomic investigation revealed an association between the NAT2* 1 SNP and a significant LDL-C decrease in response to simvastatin [61]. These findings could be potentially used to guide medical decision-makers to improve the therapeutic plan for $\mathrm{FH}$ patients. Nevertheless, the consequence of NAT2 mutations on anti-lipid pharmacokinetics has not yet been determined in FH.

The Bioavailability of statins has also been linked to other genes, including P-glycoprotein drug transporter (MDR1). MDPR1 regulates the uptake, distribution, and removal of statin from renal, hepatic, and intestinal cells. Certain polymorphisms in the MDR1 gene, such as G2677T and C3435T, can modulate statins transportation and, thus, enhance the cholesterol regulatory effect [39]. Mutations have also been noted in other pharmacokinetic modulator genes, such as ANRIL, CETP, and CYP2C9, that could contribute to the interindividual variations of FH therapy, summarized in Table $1[39,45,46]$. However, the impact of the identified variants on statin-mediated reduction of LDL-C compared to the LDLR polymorphisms is insignificant. None of them showed any significant relationship with the clinical outcomes.

\section{Pharmacogenomics of Non-Statin Lipid-Lowering Therapies in FH}

Multiple non-statin therapies effectively control cholesterol levels and could be prescribed as mono- or combined therapy in FH patients, including ezetimibe, PCSK9 inhibitors, mipomersen, and lomitapide. The latest recommendations advise intensifying the management with non-statin medicines on top of maximum statins for resistant or non-adherent statin-induced muscle pain [6]. To date, many biogenetic analyzes have been performed to examine these factors, as summarized in Table 2. However, further pharmacogenomic investigations are required to comprehensively understand the clinical response in the $\mathrm{FH}$ population. 


\subsection{Ezetimibe}

Modulation of intestinal cholesterol absorption by ezetimibe $10 \mathrm{mg}$ orally a day is another targeted pathway to further reduce the cholesterol levels in FH patients. It targets the cholesterol transporter Niemann-Pick C1-like one protein (encoded by NPC1L1) in the liver and small intestine, thus inhibiting the endogenous cholesterol synthesis and upregulating the LDLR expression. Several genetic mutations involved in lipid transfer can modulate the pharmacodynamic effects of ezetimibe treatment [29]. For instance, ezetimibe's reduction of cholesterol absorption was elevated in patients with mutations in the sterol regulatory binding protein 1 gene (SREBP-1c) [62]. Furthermore, the risk of developing ASCVD was significantly associated with a lower response to ezetimibe caused by a polymorphism in the NPC1L1 gene (rs55837134) and statins by HMGCR mutations [63] The ATP-binding cassette, subfamily G, member 5 (ABCG5) or 8 (ABCG8), plays an essential role in the intestinal secretion of cholesterol. A patient with a novel heterozygous $A B C G 5$ mutation (c.203A>T; p. Ile68Asn) manifested great sensitivity to ezetimibe and resisted the statins medication [64]. Cases such as this support the consideration of ezetimibe use for all patients with hypercholesterolemia who are resistant to HMGCR inhibitors.

Table 2. Pharmacogenomics variations associated with non-statin \& novel LLT responses in familial hypercholesterolemia patients.

\begin{tabular}{|c|c|c|c|c|c|c|c|}
\hline Gene & Significant Mutation * & Patients & Population & Sample Size & $\begin{array}{l}\text { Treatment and } \\
\text { Daily Dose }\end{array}$ & Clinical Findings & $\begin{array}{l}\text { Author, Year } \\
\text { (References) }\end{array}$ \\
\hline \multicolumn{8}{|c|}{ Non-statin Lipid-Lowering Therapies } \\
\hline LDLR & $\begin{array}{l}\text { Defective and } \\
\text { negative } L D L R\end{array}$ & Hom-FH & South African & 8 & $\begin{array}{c}\text { Evolocumab } \\
140-420 \text { mg every } \\
2-4 \text { weeks for } 3 \text { months }\end{array}$ & $\begin{array}{l}\text { Evolocumab is reducing LDL-C } \\
\text { in LDLR-defective but not in } \\
\text { negative cases }\end{array}$ & Stein et al., 2013 [65] \\
\hline LDLR & $\begin{array}{c}\text { Defective and } \\
\text { negative } L D L R\end{array}$ & Hom-FH & 10 countries ** & 50 & $\begin{array}{l}\text { Evolocumab } 420 \mathrm{mg} \\
\text { every } 4 \text { weeks for } \\
3 \text { months }\end{array}$ & $\begin{array}{l}\text { Evolocumab responses is } \\
\text { LDLR-genotype dependent with } \\
\text { higher sensitivity in } \\
\text { LDLR-defective patients }\end{array}$ & Raal et al., 2015 [66] \\
\hline PCSK9 & $\begin{array}{l}\text { rs28942111 (S127R) } \\
\text { rs28942112 (F216L) }\end{array}$ & Het-FH & 27 countries ** & 2341 & $\begin{array}{l}\text { Statin maximum dose }+ \\
\text { LLT \& alirocumab } \\
150 \mathrm{mg} / 2 \text { weeks for } \\
78 \text { weeks }\end{array}$ & $\begin{array}{l}\text { Alirocumab is significantly } \\
\text { reducing LDL-C in } P C S K 9 \\
\text { gain-of-function variants }\end{array}$ & $\begin{array}{l}\text { Robinson et al., } \\
2015[67]\end{array}$ \\
\hline$L D L R$ & c. $(1646 \mathrm{G}<\mathrm{A})$ & \multirow{2}{*}{ Hom-FH } & \multirow{2}{*}{ Italian } & \multirow{2}{*}{15} & Simvastatin $40 \mathrm{mg}$, & \multirow{2}{*}{$\begin{array}{l}\text { Lomitapide is significantly and } \\
\text { safely decreasing the } \\
\text { cholesterol levels }\end{array}$} & \multirow{2}{*}{$\begin{array}{l}\text { D'Erasmo et al., } \\
\quad 2017[68]\end{array}$} \\
\hline LDLRAP1 & c.(432_433insA) & & & & lomitapide $5-60 \mathrm{mg}$ & & \\
\hline LDLR & $\begin{array}{l}\text { Defective and } \\
\text { negative } L D L R\end{array}$ & Hom-FH & South African & 22 & $\begin{array}{l}\text { Mivastatin and } \\
\text { evolocumab }\end{array}$ & $\begin{array}{l}\text { Evolocumab is effective in } \\
\text { defective- and not in } \\
\text { negative- } L D L R \text { variants }\end{array}$ & Thedrez et al., 2017 [15] \\
\hline$A P O B$ & R3500Q (rs5742904) & Het-FH & Caucasian & 1 & $\begin{array}{l}\text { Atorvastatin } 80 \mathrm{mg} \text {, } \\
\text { ezetimibe } 10 \mathrm{mg}, \\
\text { lomitapide, \& } \\
\text { evolocumab } 140 \mathrm{mg}\end{array}$ & $\begin{array}{l}\text { ApoB defect is enhancing } \\
\text { LDL-C reduction }\end{array}$ & $\begin{array}{l}\text { Andersen et al., } \\
2017[69]\end{array}$ \\
\hline LDLRAP1 & c. 136 C > T (406) & AR-FH & German & 1 & $\begin{array}{l}\text { Atorvastatin } 80 \mathrm{mg}, \\
\text { ezetimibe } 10 \mathrm{mg}, \\
\text { lomitapide, \& } \\
\text { evolocumab } 140 \mathrm{mg}\end{array}$ & $\begin{array}{l}\text { Evolocumab is reducing LDL-C } \\
\text { by } 37 \% \text { among LDLRAP1 mutants }\end{array}$ & Fahy et al., 2017 [70] \\
\hline LDLR & Two null alleles & Hom-FH & American & 9 & $\begin{array}{c}\text { LLT } \Omega+ \\
\text { Evolocumab } 420 \\
\mathrm{mg} / 4 \text { weeks }\end{array}$ & $\begin{array}{l}\text { Evinacumab is controlling } \\
\text { cholesterol independently of } \\
L D L R \text { variants }\end{array}$ & Gaudet et al., 2017 [71] \\
\hline LDLR & $\begin{array}{l}\text { c.2043C.A, p. (Cys } \\
\text { 681A) }\end{array}$ & Het-FH & Lebanese American & 1 & $\begin{array}{c}\text { Rosuvastatin, ezetimibe, } \\
\& \\
\text { evolocumab } 140 \\
\text { mg/2 weeks for } \\
2 \text { months, then } \\
\text { alirocumab } 150 \mathrm{mg} / \\
2 \text { weeks }\end{array}$ & $\begin{array}{l}\text { Alirocumab efficacy is higher } \\
\text { than evolocumab \& standard LLT }\end{array}$ & Doyle et al., 2018 [72] \\
\hline LDLR & p.(Thr434Arg) & Hom-FH & Spanish & 2 & $\begin{array}{l}\text { LLT } \Omega \& \text { lomitapide } \\
\quad 20-40 \mathrm{mg}\end{array}$ & $\begin{array}{l}\text { Lomitapide is potent and safe as } \\
\text { adjunct therapy }\end{array}$ & Real et al., 2018 [73] \\
\hline LDLRAP1 & c. $1 \mathrm{~A}>\mathrm{G}$ & \multirow[b]{2}{*}{ AR-FH } & \multirow[b]{2}{*}{ Spanish } & \multirow[b]{2}{*}{3} & \multirow{2}{*}{$\begin{array}{c}\text { Atorvastatin, ezetimibe, } \\
\& \\
\text { evolocumab }\end{array}$} & \multirow[b]{2}{*}{$\begin{array}{l}\text { Evolocumab effecacy is lower in } \\
\text { LDLR \& LDLRAP1 variants }\end{array}$} & \multirow[b]{2}{*}{$\begin{array}{l}\text { Rodríguez-Jiménez } \\
\text { et al., 2019 [74] }\end{array}$} \\
\hline$L D L R$ & $\begin{array}{l}\text { p.(Cys352Ser) \& } \\
\text { p.(Asn825Lys) }\end{array}$ & & & & & & \\
\hline LDLR PCSK9 APOB & $\begin{array}{c}\text { p.(Trp87Gly), } \\
\text { p.(Gln254Pro), \& } \\
\text { p.(Ala627Profs*38) }\end{array}$ & Hom-FH & Chinese & 9 & $\begin{array}{l}\text { LLT } \Omega+\text { evinacumab } \\
250 \mathrm{mg}\end{array}$ & $\begin{array}{c}\text { Evinacumab is controlling } \\
\text { cholesterol independently of } \\
L D L R \text { variants }\end{array}$ & Banerjee et al., 2019 [75] \\
\hline РSСК9 & c.137 G>T, p.(Arg46Leu) & \multirow[b]{2}{*}{ Hom-FH } & \multirow[b]{2}{*}{ Caucasian } & \multirow[b]{2}{*}{3} & $\operatorname{LLT} \Omega+$ & \multirow{2}{*}{$\begin{array}{l}\text { Evolocumab is strongly reducing } \\
\text { LDL-C and CVD in PSCK9 } \\
\text { loss-of-function mutants }\end{array}$} & \multirow[b]{2}{*}{ Bayonaet al., 2020 [76] } \\
\hline LDLR & $\begin{array}{c}\text { c. } 902 \mathrm{~A}>\mathrm{G}, \\
\text { p.(Asp301Gly) }\end{array}$ & & & & $\begin{array}{l}\text { Evolocumab } 420 \mathrm{mg} / \\
4 \text { weeks }\end{array}$ & & \\
\hline LDLR & p.(Pro685Leu) & Hom-FH & Indian & 1 & $\begin{array}{l}\text { LLT } \Omega \text { \& evolocumab } \\
420 \mathrm{mg} / 4 \text { weeks }+ \\
\text { lomitapide } 5-60 \mathrm{mg}\end{array}$ & $\begin{array}{l}\text { Lomitapide is powerfully } \\
\text { reducing lipid profile and } \\
\text { CVD risk }\end{array}$ & Velvet et al., 2020 [77] \\
\hline LDLR & $\begin{array}{l}\text { Null mutation in both } \\
\text { alleles }\end{array}$ & Hom-FH & 13 countries ** & 69 & $\begin{array}{l}\text { Atorvastatin } 80 \mathrm{mg} \text {, } \\
\text { ezetimibe } 10 \mathrm{mg} \text {, } \\
\text { lomitapide, \& } \\
\text { alirocumab } \\
150 \mathrm{mg} / 2 \text { weeks for } \\
12 \text { weeks }\end{array}$ & $\begin{array}{l}\text { Alirocumab is effective in } \\
\text { controlling the lipid profile }\end{array}$ & Blom et al., 2020 [78] \\
\hline
\end{tabular}


Table 2. Cont.

\begin{tabular}{|c|c|c|c|c|c|c|c|}
\hline Gene & Significant Mutation * & Patients & Population & Sample Size & $\begin{array}{l}\text { Treatment and } \\
\text { Daily Dose }\end{array}$ & Clinical Findings & $\begin{array}{l}\text { Author, Year } \\
\text { (References) }\end{array}$ \\
\hline LDLR & $\begin{array}{l}\text { c.2027delG, } \\
\text { p.(G676Afs*33) }\end{array}$ & Hom-FH & Saudi & 2 & $\begin{array}{l}\text { Rosuvastatin } 40 \mathrm{mg} \text {, } \\
\text { ezetimibe } 10 \mathrm{mg}, \\
\text { evolocumab } \\
420 \mathrm{mg} / \mathrm{month}, \& \\
\text { lomitapide } 5-40 \mathrm{mg}\end{array}$ & $\begin{array}{l}\text { Lomitapide is robustly reducing } \\
\text { cholesterol and CVD events }\end{array}$ & Mahzari et al., 2021 [79] \\
\hline \multicolumn{8}{|c|}{ Novel Lipid-Lowering Therapies } \\
\hline $\begin{array}{l}\text { LDLR } \\
\text { APOB } \\
\text { PCSK9 }\end{array}$ & Deficient and defective & Het-FH & 9 countries *** & 306 & $\begin{array}{l}\text { LLTR \& anacetrapib } \\
100 \mathrm{mg} \text { for } 12 \text { months }\end{array}$ & $\begin{array}{l}\text { Anacetrapib is substantially } \\
\text { reducing LDL-C across all } \\
\text { genotypes }\end{array}$ & $\begin{array}{l}\text { Kastelein et al., } \\
2016[80]\end{array}$ \\
\hline$L D L R$ & $\begin{array}{l}\text { Defective and negative } \\
L D L R\end{array}$ & Hom-FH & American & 8 & $\begin{array}{l}\text { Statins, ezetimibe, } \\
\text { mipomersen, } \\
\text { lomitapide, PCSK } 9 \\
\text { inhibitors, \& gemcabene } \\
300,600 \text { or } 900 \mathrm{mg}\end{array}$ & $\begin{array}{l}\text { Gemcabene is reducing LDL-C in } \\
\text { uncontrolled cases under LLT } \\
\text { treatment }\end{array}$ & Gaudet et al., 2019 [81] \\
\hline $\begin{array}{l}\text { LDLR PCSK9 APOB } \\
\quad \text { LDLRAP1 }\end{array}$ & $\begin{array}{l}\text { Pathogenic causative } \\
\text { Gain-of-function } \\
\text { Pathogenic } \\
\text { Pathogenic }\end{array}$ & Het-FH & 8 countries $* *$ & 432 & $\begin{array}{l}\text { LLT } \Omega \text { \& inclisiran } \\
300 \mathrm{mg} / 3 \text { months }\end{array}$ & $\begin{array}{l}\text { Inclisiran is significantly reducing } \\
\text { LDL- } C \text { in } L D L R \text { variants }\end{array}$ & Raal et al., 2020 [82] \\
\hline $\begin{array}{l}L D L R \\
A P O B\end{array}$ & Pathogenic & Het-FH & Various countries ${ }^{* *}$ & 1887 & $\begin{array}{l}\text { LLT } \Omega \text {, evolocumab or } \\
\text { alirocumab, \& inclisiran }\end{array}$ & $\begin{array}{l}\text { PCSK9 inhibitors is reducing } \\
\text { LDL-C among all genetic } \\
\text { mutations }\end{array}$ & Brandts et al., 2021 [83] \\
\hline
\end{tabular}

** Various sites in Europe, Africa, the Middle East, North America, and South Africa. ${ }^{* * *}$ The 9 countries include the Netherlands, France, Spain, Canada, the USA, Germany, Russia, Norway, and the UK. LLT including ezetimibe, fibrates, statins, lomitapide, PCSK9 inhibitors, bile acid sequestrants (e.g., cholestyramine and colestipol), or niacin. Abbreviations: LLT, lipid-lowering therapies; $\mathrm{FH}$, familial hypercholesterolemia; Het-FH, patients with heterozygous FH; Hom-FH, patients with homozygous FH; ApoB, Apolipoprotein B; HDLC, High-density lipoprotein cholesterol; LDL-C, low-density lipoprotein- $C$; TC, total cholesterol; TG, triglyceride; LDLR, Low-density lipoprotein receptor; APOB, Apolipoprotein B; HMGCR, $\beta$-hydroxy- $\beta$-methylglutaryl Coenzyme A Reductase; LDLRAP1, LDLR-adaptor protein 1; PCSK9, proprotein convertase subtilin/kexin 9 genes. * Borderline significance $(p<0.05)$.

Ezetimibe is principally metabolized by the intestinal and hepatic enzymes, uridine $5^{\prime}$ diphosphate (UDP)-glucuronosyltransferase (UGT) and excreted in the urine (Figure 2) [6]. So far, genetic analysis has not presented any influence of pharmacokinetic genes on this drug.

\subsection{Monoclonal Antibodies to PCSK9}

PCSK9 enzyme is quintessential for recycling LDLR and eliminating lipoproteins from the bloodstream. The functional research recognized that decreased cholesterols and heart diseases, as well as a more extraordinary response to statins, have been presented in loss-of-function mutation carriers [55]. However, a gain of function variant (functional SNP) was linked to low LDLR expression and statins resistance [56]. Based on this genomic discovery, PCSK9 inhibitors were developed and immediately became a target for the clinical management of FH. Evolocumab, alirocumab, and inclisiran are the approved anti-PCSK9 monoclonal antibodies as an additive therapy to the aggressive treatment regimen of FH patients. These medications inhibit the PCSK9 binding with LDLR and, thus, enhance hepatic LDLR expression and reduce the circulating lipoproteins. In the mild FH phenotype, evolocumab 140-420 mg subcutaneously every 2-4 weeks raises the LDL-C reduction by $54-60 \%$, respectively. Alirocumab 75 or $150 \mathrm{mg}$ subcutaneously every two weeks has also decreased the levels of LDL-C, total cholesterol, and ApoB in heterozygous subjects by $51-58 \%$ [72]. Interestingly, the response to PCSK9 inhibitors is influenced by the baseline mutations in homozygous and heterozygous FH individuals.

Different responses to anti-PCSK9 monoclonal antibodies have been reported with superior sensitivity to alirocumab compared with evolocumab. This differential efficacy was found in patients with heterozygous $\mathrm{FH}$ and those at high CVD risk and resistance to statins $[67,72]$. Blom and colleagues recently demonstrated that the combination of alirocumab with classical therapy in homozygous cases carrying double $L D L R$ allele leads to notable regulating of the plasma lipids [78]. Conversely, the optimizing of low LDL$\mathrm{C}$ is hardly obtained with evolocumab treatment in homozygous $\mathrm{FH}$ patients carrying nonfunctional $L D L R$ due to the $L D L R$-dependent mechanism of such agents [66]. Numerous analyses have concluded that the pharmacological effect of evolocumab is based on the phenotype-genotype mutation of $L D L R$. They found that subjects carrying defective $L D L R$ alleles are highly sensitive to treatment and those with an autosomal recessive $\mathrm{FH}$ are moderately sensitive. At the same time, individuals with no LDLR function (receptor- 
negative mutations) do not respond to evolocumab $[15,65,81]$. Generally, the therapeutic efficacy of evolocumab was found to be dependent on various phenotypes.

The LDLRAP1 genotype (c.1A > G) was associated with an attenuated response of autosomal recessive $\mathrm{FH}$ patients to evolocumab [74]. Reciprocally, a higher reduction of LDL-C was observed by evolocumab in patients carrying another LDLRAP1 variant (c.136 C > T (406)) with resistance to traditional medications [70]. This observation disproves the fact that evolocumab would not demonstrate an effective response in patients with LDLRAP1 variants. Patients with homozygous FH resulted from gain-of-function missense variants in PCSK9, and two mutant alleles of $L D L R$ genes might have a worse phenotype with negligible response to anti-PCSK9 antibodies and statins $[48,76]$. Compared to heterozygous FH subjects with typical $L D L R$ mutations, those with a gain-of-function variant, D374Y PCSK9, havda more aggressive phenotype with excessive lipid levels, risk of CVD, and poor sensitivity to lipid-neutralizing medicines [84]. This indicates that the intensity of FH depends on the functional genetic mutation in addition to the number of defected alleles, homozygosity, and heterozygosity.

The phase 3 ORION pilot studies manifested that inclisiran $300 \mathrm{mg}$ twice a year could robustly minimize cholesterol concentrations by $50 \%$ and PCSK9 by $70 \%$ in $\mathrm{FH}$ patients with heart defects. Inclisiran $300 \mathrm{mg}$ subcutaneously is a novel and the only approved small interfering RNA (siRNA) agent that selectively inhibits the hepatocyte synthesis of PCSK9 [6]. Remarkably, a greater LDL-C reduction was observed after the second dose administration compared to only a single dose with an acceptable safety profile. The suspended therapeutic effect of siRNA with a low administration frequency is a unique advantage of inclisiran over other adjunct anti-lipids. It provides a long-term adherence that minimizes CVD events in patients at high risk. Raal et al. recognized that inclisiran powerfully and safely decreases the cholesterol levels among all cases of mild $\mathrm{FH}$ genotype carrying disease-causative polymorphisms, including LDLR, APOB, PCSK9, and LDLRAP1 [82]. A very recent meta-analysis study in heterozygous $\mathrm{FH}$ subjects carrying different phenotypes has observed similar physiological effects of anti-lipids targeting PCSK9 [83].

PCSK9 inhibitors are known to be eliminated through the intestinal pathway and bypassing hepatic metabolism (Figure 2). Remarkably, kinetic studies confirmed that negative $A P O B$ carriers have a lower serum concentration of alirocumab than those with PCSK9 gain-of-function variants [85]. In support of this, another genetic analysis proved a significant therapeutic response to anti-PCSK9 antibodies in FH patients with $A P O B$ variants (rs5742904) [69]. Another antibody against PCSK9, bococizumab $150 \mathrm{mg}$ subcutaneously every other week, was characterized by a weak nontoxic profile along with a short-term attenuation of LDL-C due to the great neutralizing force of the defending antibodies [50]. Considering the cost-benefit analysis of this medication, it can possibly be used in $\mathrm{FH}$ cases at high risk of CVD [6]. The genomic examination of $\mathrm{FH}$ patients at risk for $P C S K 9 / L D L R$ and $A P O B$ polymorphisms has become necessary to ameliorate clinical diagnosis and management by considering the use of PCSK9 inhibitors in their therapeutic care plan.

\subsection{Mipomersen}

Mipomersen $200 \mathrm{mg}$ subcutaneously per week is recommended as an adjunct to standard anti-lipid therapy with a low-fat diet in homozygous FH patients. A secondgeneration antisense oligonucleotide (ASO) lowers cholesterol through selective degradation of hepatic ApoB-100 messenger ribonucleic acid (mRNA) transcript. This ultimately leads to a sustained reduction of atherogenic ApoB-100 containing lipoproteins, including lipoprotein, VLDL, and LDL-C, via an LDLR-independent pathway. This pathway was targeted because rare $A P O B$ polymorphisms are one of the causative factors of $\mathrm{FH}$. Although the FDA has approved the use of mipomercen in FH patients, the European Committee for Medicinal Products for Humans has terminated mipomersen due to its life-threatening hepatotoxicity [6]. 
Interestingly, mipomersen has a wide interindividual variability in controlling lipid levels among homozygous and heterozygous individuals. Mipomercin was associated with a $21 \%$ decrease in LDL-C, a $25 \%$ reduction in lipoproteins, and a $22 \%$ decrease in ApoB levels in patients with heterozygous $\mathrm{FH}$ [86]. In homozygous cases, the combination of mipomersen and standard lipid-lowering therapy was accompanied by ApoB reduction of $46 \%$ and LDL-C reduction of $42 \%$ [87]. The metabolism of mipomersen does not depend on conventional drug-metabolizing enzymes, and thus does not interact with concomitant agents and is excreted mainly through the urinary pathway [86]. In general, mipomersen could significantly reduce ApoB and LDL-C but with limited tolerability and variable effect in FH patients.

\subsection{Lomitapide}

The MTP protein plays a substantial role in VLDL and chylomicron's hepatic and intestinal assembly, respectively. Loss-of-function mutations in MTP result in limited plasma levels of ApoB-48 and ApoB-100 in addition to hypocholesterolemia [88]. Another examination confirmed that MTP -493 GT SNP has a gender-specific restriction of atorvastatin-induced lipid reduction [38]. This suggests targeting MTP to manage hypercholesterolemia. Lomitapide 5-60 mg orally per day is the only approved MTP inhibitor to treat patients with homozygous FH. Severe defect in LDLR and CYP3A4 function attenuates the drug efficiency that targets LDL-C elimination [6]. It inhibits the secretion of lipoproteins into the bloodstream and reduces the LDL-C by $38 \%$ combined in homozygous FH patients. D'Erasmo and colleagues illustrated that a combination of lomitapide with traditional medicines in cases with the severe $\mathrm{FH}$ phenotype had been correlated with a very efficient and well-tolerated lipid reduction [68]. In India, it was found that using a PCSK9 inhibitor, evolocumab $420 \mathrm{mg}$ every month, combined with standard therapy in homozygous FH patients carrying impaired $L D L R$ activity was ineffective in controlling plasma lipids or limiting the number of heart diseases. The addition of lomitapide powerfully reduced $54 \%$ of the LDL-C and $15 \%$ of major coronary artery diseases [77]. Thus, utilizing lomitapide as adjunct therapy can potentially and safely optimize the reduction of LDL-C through genotype-independent effects in FH subjects [73,79].

\section{Pharmacogenomics of Novel Lipid-Lowering Therapies in FH}

Based on the knowledge of pathological genetic mutations involved in the intrinsic or extrinsic cholesterol pathways, therapeutic research has discovered novel strategies with unique mechanisms that substantially enhance the management of dyslipidemia. Gene-based medicines are categorized into integrated genomic replacement treatment that inserts healthy genes to replace pathological mutants, modification of gene expression, and transcription that target coding or noncoding RNAs to alter singling or splicing mechanisms and, ultimately genome modification to insert or delete a specific genetic sequence [2]. Gene therapy showed potent and persistent reduction of LDL-C and elevation of LDLR expression in homozygous FH by restoring the functional hepatic LDL-C elimination [89].

Numerous emerging or new pharmacological approaches are designated to target functional genes for the management of unresponsive or severe FH (Table 2 and Figure 1). However, little is known about the efficiency and resistance of such strategies among FH patients with different genotypes.

\subsection{Evinacumab}

Loss of function mutations in hepatic angiopoietin-like protein 3 (ANGPTL3) results in low levels of LDL-C, high-density lipoprotein cholesterol (HDL-C; good cholesterol), and triglyceride. Evinacumab $15 \mathrm{mg} / \mathrm{kg}$ intravenously every month is a new monoclonal antibody treatment targeting the ANGPTL3 protein, an endogenous lipoprotein lipase inhibitor [6]. Importantly, this inhibitory mechanism leads to well-tolerated and powerful triglyceride depletion by $50 \%$, HDL-C by $30 \%$, and LDL-C by $47 \%$ via bypassing the LDLR expression [90]. Multiple investigations have confirmed that evinacumab can effectively 
optimize a minimal level of LDL-C in patients with homozygous and heterozygous $\mathrm{FH}$ independently of $L D L R$ mutations [71,75]. This provides a highly targeted approach to treat individuals with $L D L R$ impairments who are resistant to other anti-lipids, such as PCSK9 and HMGCR inhibitors. The ANGPTL3 inhibitor was recently approved to be prescribed on top of an aggressive lipid-lowering treatment for homozygous $\mathrm{FH}$ pediatric patients of 12 years of age or more depending on the phase 3 ELIPSE trial [90].

\subsection{Bempedoic Acid}

Bempedoic acid $180 \mathrm{mg}$ by oral daily is another newly approved cholesterol-lowering treatment for FH subjects with CVD and statin intolerance. It is a robust adenosine triphosphate citrate lyase (ACL) inhibitor and an activator of AMP-activated protein kinase (AMPK) in the liver. This ACL inhibitor is an inactive agent that is activated through the metabolic activity of a very-long-chain acyl-CoA synthetase-1 (ACSVL1), and then deactivates via UGT hepatic enzymes. The direct mechanism of bempedoic acid is to restrict cholesterol and fatty acid production, thus upregulating hepatic LDLR and depleting cholesterol, inflammatory C-reactive protein, and LDL-C [6]. The combination of bempedoic acid along with atorvastatin and ezetimibe has been associated with a fundamental and long-term reduction of cholesterol by nearly $50 \%$ and C-reactive protein by $40 \%$ across FH patients at high risk of ASCVD with no major toxicities [91]. This ACL inhibitor is an inactive agent that is activated through the metabolic activity of very-longchain acyl-CoA synthetase-1 (ACSVL1) and then deactivated via UGT hepatic enzymes.

\subsection{Gemcabene}

A novel lipid-regulating mechanism has been established in gemcabene which promotes apolipoprotein molecule degradation through decreasing the messenger RNA of apolipoprotein C-III (ApoC-III) in the liver. Up to the present time, gemcabene 450 to $900 \mathrm{mg}$ orally a day has been found to be effective and well-tolerated among many different patient groups for three months. It can exceedingly diminish ApoB, C-reactive protein, and LDL-C by $30 \%$, as well as raise HDL-C in FH patients on top of optimal therapy independently of LDLR. Importantly, gemcabene effectively reduced LDL-C levels by $44 \%$ in homozygous FH patients with negative- $L D L R$ mutations [81]. This indicates that gemcabene could be used in patients with nonfunctional LDLR that are resistant to statins and PCSK9 inhibitors.

\subsection{CETP Inhibitor}

Cholesteryl ester transfer protein (CETP) is responsible for the heteroexchange between atherogenic ApoB-lipoproteins, particularly VLDL, and HDL-C of triglycerides and cholesteryl esters. Distinctively, it is characterized by a long-acting kinetic effect caused by the increased adipose tissue accumulation. The lack of CETP activity caused by genetic defects was accompanied by low LDL-C levels and a consequent CVD risk, as well as elevated HDL-C. Anacetrapib, a new direct inhibitor of CEPT, was analyzed in a large cohort cardiovascular study. A substantial 9\% reduction of major CVD accompanied by nearly $30 \%$ reduction of cholesterols was reported in heterozygous FH cases [92]. Nevertheless, despite the acceptable nontoxic profile, the sponsor decided to discontinue the anacetrapib commercialization and has not proposed that it get clinical approval. A global study was conducted on a large population of heterozygous FH patients who have been treated with anacetrapib $100 \mathrm{mg}$ orally a day for up to 52 weeks as adjunctive therapy to optimal anti-lipids. It found an almost $40 \%$ decrease in LDL-C [80]. The cholesterol reduction observed in these cases holds future promise in terms of managing cases with unmanaged $\mathrm{FH}$ who are resistant to the most aggressive therapies.

\section{Conclusions and Clinical Prospect of the Future}

The overburden of prolonged hypercholesterolemia increases the incidence of lifethreatening consequences such as myocardial infarction, especially in $\mathrm{FH}$ patients who are 
generally undiagnosed and uncontrolled. Despite the improvements in lipid-neutralizing therapies, several genetic and non-genetic factors may greatly influence the pharmacodynamic and pharmacokinetic pathways. Throughout the past decade there has been an unprecedented development in the study of genetic variants. Emerging approaches to pharmacogenetic analysis have extended the clinical surveillance of novel candidate genotypes and phenotypes, improving our knowledge of the biochemical effect of antilipids and the impact of genetic variations on clinical outcomes. As a result, various new anti-lipids have been discovered, depending on the discovered novel and rare mutations in addition to the genetic pathophysiology of diverse rare diseases, including FH. However, pharmacogenomics' lack of appropriate medical implications has drastically impacted the optimal treatment of many pathologies.

Ideally, future pharmacogenomic analysis of lipid-regulating agents should focus on including various ethnic backgrounds as well as on understanding and comparing the impact of genetic/epigenetic variants on the anti-lipid's physiological pathways. The exploitation of GWAS results for ethnic groups is needed to promote medical outcomes and prevent major complications, such as ASCVD, for FH or dyslipidemia patients. Therefore, whole-genome sequencing can contribute significantly to the personalization of $\mathrm{FH}$ therapeutic regimens based on the patient's complete genetic profile. Consequently, we proposed the strategy of diagnosing and managing patients with $\mathrm{FH}$ and their families according to current guidelines as illustrated in Figure 3 [6]. We strongly recommend genomic screening for patient-specific variants prior to treatment, particularly for subjects with major pathogenic polymorphisms. Furthermore, patients and their families should be counseled about the advantages of detecting the disease-causative gene mutations as well as utilizing novel anti-lipids such as evinacumab, inclisiran, gemcabene, and anacetrapib in severe and unresponsive FH cases. Ultimately, regular clinical follow-up is strongly recommended in our strategy to determine interindividual variability of therapeutic outcomes among patients of different genotypes. If applied appropriately, this gene-based, personalized medicine and evaluation will help to promote drug potency, tolerability, and safety as well as to sustain a healthy quality of life in patients with hereditary diseases.

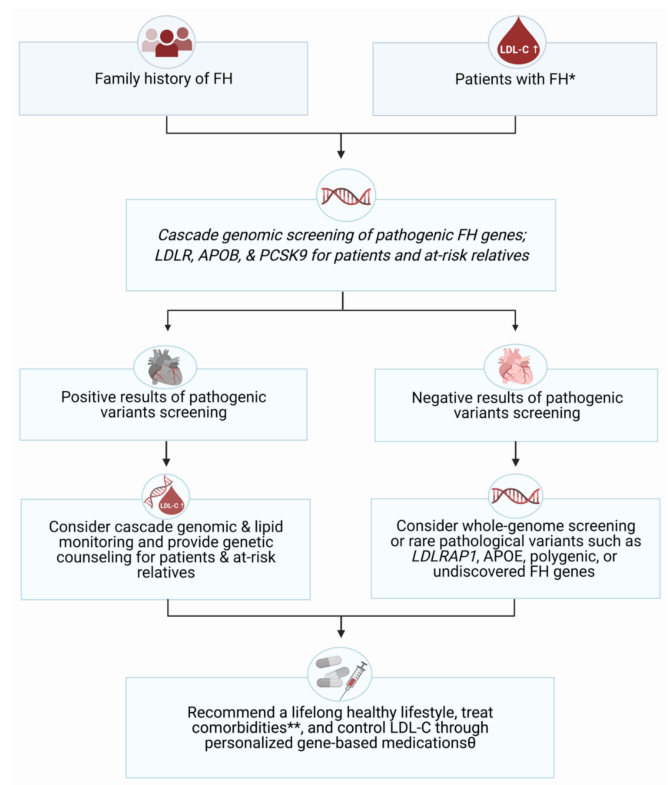

Figure 3. Flowchart illustration of the recommended genomic screening process for different groups of FH patients and their families (generated with BioRender.com). ${ }^{*}$ Diagnostic Criteria of FH based on Dutch-MEDPED guideline: total cholesterol > $250 \mathrm{mg} / \mathrm{dL}, \mathrm{LDL}-\mathrm{C}>190 \mathrm{mg} / \mathrm{dL}$ (adults) or $>160 \mathrm{mg} / \mathrm{dL}$ (children), in addition to family history of similar findings or with premature cardiovascular diseases, tendon xanthomas, arcus cornealis, or DNA-based evidence of LDLR, APOB, 
or PCSK9 functionality mutations [6]. ** Morbidities associated with FH: cardiovascular diseases such as coronary heart disease, stroke, \& peripheral vascular disease, diabetes, hypertension, and erectile dysfunction. $\Theta$ Regularly monitor and compare the response and safety of medications according to each individual genotypes. Abbreviations: LDL-C, low-density lipoprotein-cholesterol; $L D L R$, LDL-receptor; $A P O B$, Apolipoprotein B; PCSK9, proprotein convertase subtilin/kexin 9 protein, LDLRAP1, LDLR-adaptor protein, member 1, APOE, Apolipoprotein E.

Author Contributions: G.N. developed the idea and defined the contents of the manuscript. N.N.H. and J.A. performed literature search and data analysis. N.N.H. and J.A. wrote the first draft, and N.N.H. generated the figures and the tables. All authors have read and agreed to the published version of the manuscript.

Funding: This research received no external funding.

Institutional Review Board Statement: Not applicable.

Informed Consent Statement: Not applicable.

Data Availability Statement: Not applicable.

Acknowledgments: The schematic representations were generated using Biorender.com.

Conflicts of Interest: The authors declare that the research was conducted in the absence of any relevant affiliations or commercial or financial relationships that could be construed as a potential conflict of interest. No writing assistance was used in preparation of the manuscript.

\begin{abstract}
Abbreviations
LLT, lipid-lowering therapies; FH, familial hypercholesterolemia; Het-FH, patients with heterozygous FH; Hom-FH, patients with homozygous FH; ApoB, Apolipoprotein B; HDL-C, High-density lipoprotein cholesterol; LDL-C, low-density lipoprotein-C; TC, total cholesterol; TG, triglyceride; LDLR, Low-density lipoprotein receptor; APOB, Apolipoprotein B; HMGCR, $\beta$-hydroxy- $\beta$-methylglutaryl Coenzyme A Reductase; LDLRAP1, LDLR-adaptor protein 1; PCSK9, proprotein convertase subtilin/kexin 9 genes; ABCG2/5/8, atp-binding cassette, subfamily g, member 2, 5, or 8; SLCO1B1, solute carrier organic anion transporter 1B1; CYP3A4, Cytochrome P450, family 3, subfamily A, member 4; UGT2B7, uridine 5'-diphosphate (UDP)-glucuronosyltransferase 2B7; UGT1A1/3, uridine $5^{\prime}$-diphosphate (UDP)-glucuronosyltransferase 1A1 or 3; PCVD, premature cardiovascular diseases; MDR1, multidrug resistance mutation 1; ANRIL, antisense non-coding RNA in the INK4 locus; POR, Cytochrome P450 Oxidoreductase; MYLIP, Myosin Regulatory Light Chain Interacting Protein; ApoB-48/100, Apolipoprotein B protein member 48 \& 100; ApoC-III, Apolipoprotein C protein, member III; ApoE, Apolipoprotein E protein; ACL, adenosine triphosphate citrate lyase; MTP, microsomal triglyceride transfer protein; LPL, lipoprotein lipase; CETP, cholesteryl ester transfer protein; ANGPTL3, angiopoietin-like protein 3.
\end{abstract}

\title{
References
}

1. Khachadurian, A.K. The Inheritance of Essential Familial Hypercholesterolemia. Am. J. Med. 1964, 37, 402-407. [CrossRef]

2. Lui, D.T.W.; Lee, A.C.H.; Tan, K.C.B. Management of Familial Hypercholesterolemia: Current Status and Future Perspectives. J. Endocr. Soc. 2021, 5, bvaa122. [CrossRef] [PubMed]

3. Hayat, M.; Kerr, R.; Bentley, A.R.; Rotimi, C.N.; Raal, F.J.; Ramsay, M. Genetic associations between serum low LDL-cholesterol levels and variants in LDLR, APOB, PCSK9 and LDLRAP1 in African populations. PLoS ONE 2020, 15, e0229098, Correction in 2021, 16, e0249478. [CrossRef]

4. Fahed, A.C.; Nemer, G.M. Familial hypercholesterolemia: The lipids or the genes? Nutr. Metab. 2011, 8, 23. [CrossRef]

5. Galema-Boers, A.M.; Lenzen, M.J.; Engelkes, S.R.; Sijbrands, E.J.; Roeters van Lennep, J.E. Cardiovascular risk in patients with familial hypercholesterolemia using optimal lipid-lowering therapy. J Clin. Lipidol. 2018, 12, 409-416. [CrossRef] [PubMed]

6. Corrigendum to: 2019 ESC/EAS Guidelines for the management of dyslipidaemias: Lipid modification to reduce cardiovascular risk. Eur. Heart J. 2020, 41, 4255. [CrossRef] [PubMed]

7. Kamar, A.; Khalil, A.; Nemer, G. The Digenic Causality in Familial Hypercholesterolemia: Revising the Genotype-Phenotype Correlations of the Disease. Front. Genet. 2020, 11, 572045. [CrossRef] 
8. $\quad$ Borges, J.B.; Oliveira, V.F.; Ferreira, G.M.; Los, B.; Barbosa, T.; Marcal, E.; Dagli-Hernandez, C.; de Freitas, R.C.C.; Bortolin, R.H.; Mori, A.A.; et al. Genomics, epigenomics and pharmacogenomics of familial hypercholesterolemia (FHBGEP): A study protocol. Res. Soc. Adm. Pharm. 2021, 17, 1347-1355. [CrossRef]

9. Chahine, J.; Kreykes, S.; Van't Hof, J.R.; Duprez, D.; Nijjar, P. Variable and Severe Phenotypic Expression of the "Lebanese Allele" in Two Sisters with Familial Hypercholesterolemia. Vasc. Health Risk Manag. 2021, 17, 415-419. [CrossRef]

10. Fahed, A.C.; Bitar, F.F.; Khalaf, R.I.; Moubarak, E.M.; Azar, S.T.; Nemer, G.M. The Lebanese allele at the LDLR in normocholesterolemic people merits reconsideration of genotype phenotype correlations in familial hypercholesterolemia. Endocrine 2012, 42, 445-448. [CrossRef]

11. Hartgers, M.L.; Besseling, J.; Stroes, E.S.; Wittekoek, J.; Rutten, J.H.W.; de Graaf, J.; Visseren, F.L.J.; Imholz, B.P.M.; Roeters van Lennep, J.E.; Huijgen, R.; et al. Achieved LDL cholesterol levels in patients with heterozygous familial hypercholesterolemia: A model that explores the efficacy of conventional and novel lipid-lowering therapy. J. Clin. Lipidol. 2018, 12, 972-980.e1. [CrossRef]

12. Marziliano, N.; Medoro, A.; Mignogna, D.; Saccon, G.; Folzani, S.; Reverberi, C.; Russo, C.; Intrieri, M. Sudden Cardiac Death Caused by a Fatal Association of Hypertrophic Cardiomyopathy (MYH7, p.Arg719Trp), Heterozygous Familial Hypercholesterolemia (LDLR, p.Gly343Lys) and SARS-CoV-2 B.1.1.7 Infection. Diagnostics 2021, 11, 1229. [CrossRef] [PubMed]

13. Luirink, I.K.; Wiegman, A.; Kusters, D.M.; Hof, M.H.; Groothoff, J.W.; de Groot, E.; Kastelein, J.J.P.; Hutten, B.A. 20-Year Follow-up of Statins in Children with Familial Hypercholesterolemia. N. Engl. J. Med. 2019, 381, 1547-1556. [CrossRef] [PubMed]

14. Perez de Isla, L.; Alonso, R.; Watts, G.F.; Mata, N.; Saltijeral Cerezo, A.; Muniz, O.; Fuentes, F.; Diaz-Diaz, J.L.; de Andres, R.; Zambon, D.; et al. Attainment of LDL-Cholesterol Treatment Goals in Patients With Familial Hypercholesterolemia: 5-Year SAFEHEART Registry Follow-Up. J. Am. Coll. Cardiol. 2016, 67, 1278-1285. [CrossRef] [PubMed]

15. Thedrez, A.; Blom, D.J.; Ramin-Mangata, S.; Blanchard, V.; Croyal, M.; Chemello, K.; Nativel, B.; Pichelin, M.; Cariou, B.; Bourane, S.; et al. Homozygous Familial Hypercholesterolemia Patients With Identical Mutations Variably Express the LDLR (Low-Density Lipoprotein Receptor): Implications for the Efficacy of Evolocumab. Arter. Thromb. Vasc. Biol. 2018, 38, 592-598. [CrossRef]

16. Fahed, A.C.; El-Hage-Sleiman, A.K.; Farhat, T.I.; Nemer, G.M. Diet, genetics, and disease: A focus on the middle East and north Africa region. J. Nutr. Metab. 2012, 2012, 109037. [CrossRef]

17. Ramaswami, U.; Futema, M.; Bogsrud, M.P.; Holven, K.B.; Roeters van Lennep, J.; Wiegman, A.; Descamps, O.S.; Vrablik, M.; Freiberger, T.; Dieplinger, H.; et al. Comparison of the characteristics at diagnosis and treatment of children with heterozygous familial hypercholesterolaemia (FH) from eight European countries. Atherosclerosis 2020, 292, 178-187. [CrossRef]

18. Carr, D.F.; Francis, B.; Jorgensen, A.L.; Zhang, E.; Chinoy, H.; Heckbert, S.R.; Bis, J.C.; Brody, J.A.; Floyd, J.S.; Psaty, B.M.; et al. Genomewide Association Study of Statin-Induced Myopathy in Patients Recruited Using the UK Clinical Practice Research Datalink. Clin. Pharm. Ther. 2019, 106, 1353-1361. [CrossRef] [PubMed]

19. Jeenah, M.; September, W.; Graadt van Roggen, F.; de Villiers, W.; Seftel, H.; Marais, D. Influence of specific mutations at the LDLreceptor gene locus on the response to simvastatin therapy in Afrikaner patients with heterozygous familial hypercholesterolaemia. Atherosclerosis 1993, 98, 51-58. [CrossRef]

20. Kajinami, K.; Yagi, K.; Higashikata, T.; Inazu, A.; Koizumi, J.; Mabuchi, H. Low-density lipoprotein receptor genotype-dependent response to cholesterol lowering by combined pravastatin and cholestyramine in familial hypercholesterolemia. Am. J. Cardiol. 1998, 82, 113-117. [CrossRef]

21. Couture, P.; Brun, L.D.; Szots, F.; Lelievre, M.; Gaudet, D.; Despres, J.P.; Simard, J.; Lupien, P.J.; Gagne, C. Association of specific LDL receptor gene mutations with differential plasma lipoprotein response to simvastatin in young French Canadians with heterozygous familial hypercholesterolemia. Arter. Thromb. Vasc. Biol. 1998, 18, 1007-1012. [CrossRef]

22. Salazar, L.A.; Cavalli, S.A.; Hirata, M.H.; Diament, J.; Forti, N.; Giannini, S.D.; Nakandakare, E.R.; Bertolami, M.C.; Hirata, R.D. Polymorphisms of the low-density lipoprotein receptor gene in Brazilian individuals with heterozygous familial hypercholesterolemia. Braz. J. Med. Biol. Res. 2000, 33, 1301-1304. [CrossRef] [PubMed]

23. Leitersdorf, E.; Eisenberg, S.; Eliav, O.; Friedlander, Y.; Berkman, N.; Dann, E.J.; Landsberger, D.; Sehayek, E.; Meiner, V.; Wurm, M.; et al. Genetic determinants of responsiveness to the HMG-CoA reductase inhibitor fluvastatin in patients with molecularly defined heterozygous familial hypercholesterolemia. Circulation 1993, 87, III35-44.

24. Miltiadous, G.; Xenophontos, S.; Bairaktari, E.; Ganotakis, M.; Cariolou, M.; Elisaf, M. Genetic and environmental factors affecting the response to statin therapy in patients with molecularly defined familial hypercholesterolaemia. Pharm. Genom. 2005, 15, 219-225. [CrossRef] [PubMed]

25. Polisecki, E.; Muallem, H.; Maeda, N.; Peter, I.; Robertson, M.; McMahon, A.D.; Ford, I.; Packard, C.; Shepherd, J.; Jukema, J.W.; et al. Genetic variation at the LDL receptor and HMG-CoA reductase gene loci, lipid levels, statin response, and cardiovascular disease incidence in PROSPER. Atherosclerosis 2008, 200, 109-114. [CrossRef] [PubMed]

26. Muallem, H.; North, K.E.; Kakoki, M.; Wojczynski, M.K.; Li, X.; Grove, M.; Boerwinkle, E.; Wilhelmsen, K.C.; Heiss, G.; Maeda, N. Quantitative effects of common genetic variations in the $3^{\prime} \mathrm{UTR}$ of the human LDL-receptor gene and their associations with plasma lipid levels in the Atherosclerosis Risk in Communities study. Hum. Genet. 2007, 121, 421-431. [CrossRef]

27. Mangravite, L.M.; Medina, M.W.; Cui, J.; Pressman, S.; Smith, J.D.; Rieder, M.J.; Guo, X.; Nickerson, D.A.; Rotter, J.I.; Krauss, R.M. Combined influence of LDLR and HMGCR sequence variation on lipid-lowering response to simvastatin. Arter. Thromb. Vasc. Biol. 2010, 30, 1485-1492. [CrossRef] 
28. Lahoz, C.; Pena, R.; Mostaza, J.M.; Laguna, F.; Garcia-Iglesias, M.F.; Taboada, M.; Pinto, X. Baseline levels of low-density lipoprotein cholesterol and lipoprotein (a) and the AvaII polymorphism of the low-density lipoprotein receptor gene influence the response of low-density lipoprotein cholesterol to pravastatin treatment. Metabolism 2005, 54, 741-747. [CrossRef]

29. Awan, Z.A.; Rashidi, O.M.; Al-Shehri, B.A.; Jamil, K.; Elango, R.; Al-Aama, J.Y.; Hegele, R.A.; Banaganapalli, B.; Shaik, N.A. Saudi Familial Hypercholesterolemia Patients With Rare LDLR Stop Gain Variant Showed Variable Clinical Phenotype and Resistance to Multiple Drug Regimen. Front. Med. 2021, 8, 694668. [CrossRef]

30. Santos, P.C.; Morgan, A.C.; Jannes, C.E.; Turolla, L.; Krieger, J.E.; Santos, R.D.; Pereira, A.C. Presence and type of low density lipoprotein receptor (LDLR) mutation influences the lipid profile and response to lipid-lowering therapy in Brazilian patients with heterozygous familial hypercholesterolemia. Atherosclerosis 2014, 233, 206-210. [CrossRef] [PubMed]

31. Heath, K.E.; Gudnason, V.; Humphries, S.E.; Seed, M. The type of mutation in the low density lipoprotein receptor gene influences the cholesterol-lowering response of the HMG-CoA reductase inhibitor simvastatin in patients with heterozygous familial hypercholesterolaemia. Atherosclerosis 1999, 143, 41-54. [CrossRef]

32. Chaves, F.J.; Real, J.T.; Garcia-Garcia, A.B.; Civera, M.; Armengod, M.E.; Ascaso, J.F.; Carmena, R. Genetic diagnosis of familial hypercholesterolemia in a South European outbreed population: Influence of low-density lipoprotein (LDL) receptor gene mutations on treatment response to simvastatin in total, LDL, and high-density lipoprotein cholesterol. J. Clin. Endocrinol. Metab. 2001, 86, 4926-4932. [CrossRef]

33. Sun, X.M.; Patel, D.D.; Knight, B.L.; Soutar, A.K. Influence of genotype at the low density lipoprotein (LDL) receptor gene locus on the clinical phenotype and response to lipid-lowering drug therapy in heterozygous familial hypercholesterolaemia. The Familial Hypercholesterolaemia Regression Study Group. Atherosclerosis 1998, 136, 175-185. [CrossRef]

34. Sanna, C.; Stephenne, X.; Revencu, N.; Smets, F.; Sassolas, A.; Di Filippo, M.; Descamps, O.S.; Sokal, E.M. Homozygous familial hypercholesterolemia in childhood: Genotype-phenotype description, established therapies and perspectives. Atherosclerosis 2016, 247, 97-104. [CrossRef] [PubMed]

35. Carmena, R.; Roederer, G.; Mailloux, H.; Lussier-Cacan, S.; Davignon, J. The response to lovastatin treatment in patients with heterozygous familial hypercholesterolemia is modulated by apolipoprotein E polymorphism. Metabolism 1993, 42, 895-901. [CrossRef]

36. O'Neill, F.H.; Patel, D.D.; Knight, B.L.; Neuwirth, C.K.; Bourbon, M.; Soutar, A.K.; Taylor, G.W.; Thompson, G.R.; Naoumova, R.P. Determinants of variable response to statin treatment in patients with refractory familial hypercholesterolemia. Arter. Thromb. Vasc. Biol. 2001, 21, 832-837. [CrossRef] [PubMed]

37. Vohl, M.C.; Szots, F.; Lelievre, M.; Lupien, P.J.; Bergeron, J.; Gagne, C.; Couture, P. Influence of LDL receptor gene mutation and apo E polymorphism on lipoprotein response to simvastatin treatment among adolescents with heterozygous familial hypercholesterolemia. Atherosclerosis 2002, 160, 361-368. [CrossRef]

38. Garcia-Garcia, A.B.; Gonzalez, C.; Real, J.T.; Martin de Llano, J.J.; Gonzalez-Albert, V.; Civera, M.; Chaves, F.J.; Ascaso, J.F.; Carmena, R. Influence of microsomal triglyceride transfer protein promoter polymorphism -493 GT on fasting plasma triglyceride values and interaction with treatment response to atorvastatin in subjects with heterozygous familial hypercholesterolaemia. Pharm. Genom. 2005, 15, 211-218. [CrossRef]

39. Bercovich, D.; Friedlander, Y.; Korem, S.; Houminer, A.; Hoffman, A.; Kleinberg, L.; Shochat, C.; Leitersdorf, E.; Meiner, V. The association of common SNPs and haplotypes in the CETP and MDR1 genes with lipids response to fluvastatin in familial hypercholesterolemia. Atherosclerosis 2006, 185, 97-107. [CrossRef]

40. Alonso, R.; Mata, N.; Castillo, S.; Fuentes, F.; Saenz, P.; Muniz, O.; Galiana, J.; Figueras, R.; Diaz, J.L.; Gomez-Enterria, P.; et al. Cardiovascular disease in familial hypercholesterolaemia: Influence of low-density lipoprotein receptor mutation type and classic risk factors. Atherosclerosis 2008, 200, 315-321. [CrossRef]

41. Hu, M.; Lui, S.S.; Mak, V.W.; Chu, T.T.; Lee, V.W.; Poon, E.W.; Tsui, T.K.; Ko, G.T.; Baum, L.; Tam, L.S.; et al. Pharmacogenetic analysis of lipid responses to rosuvastatin in Chinese patients. Pharm. Genom. 2010, 20, 634-637. [CrossRef]

42. Mata, N.; Alonso, R.; Badimon, L.; Padro, T.; Fuentes, F.; Muniz, O.; Perez-Jimenez, F.; Lopez-Miranda, J.; Diaz, J.L.; Vidal, J.I.; et al. Clinical characteristics and evaluation of LDL-cholesterol treatment of the Spanish Familial Hypercholesterolemia Longitudinal Cohort Study (SAFEHEART). Lipids Health Dis 2011, 10, 94. [CrossRef] [PubMed]

43. Schaefer, J.R.; Kurt, B.; Sattler, A.; Klaus, G.; Soufi, M. Pharmacogenetic aspects in familial hypercholesterolemia with the special focus on FHMarburg (FH p.W556R). Clin. Res. Cardiol. Suppl. 2012, 7, 2-6. [CrossRef] [PubMed]

44. Rosales, A.; Alvear, M.; Cuevas, A.; Saavedra, N.; Zambrano, T.; Salazar, L.A. Identification of pharmacogenetic predictors of lipid-lowering response to atorvastatin in Chilean subjects with hypercholesterolemia. Clin. Chim. Acta 2012, 413, 495-501. [CrossRef]

45. Ahmed, W.; Ali, I.S.; Riaz, M.; Younas, A.; Sadeque, A.; Niazi, A.K.; Niazi, S.H.; Ali, S.H.; Azam, M.; Qamar, R. Association of ANRIL polymorphism (rs1333049:C>G) with myocardial infarction and its pharmacogenomic role in hypercholesterolemia. Gene 2013, 515, 416-420. [CrossRef]

46. Drogari, E.; Ragia, G.; Mollaki, V.; Elens, L.; Van Schaik, R.H.; Manolopoulos, V.G. POR²8 SNP is associated with lipid response to atorvastatin in children and adolescents with familial hypercholesterolemia. Pharmacogenomics 2014, 15, 1963-1972. [CrossRef] [PubMed] 
47. Santos, P.C.; Morgan, A.C.; Jannes, C.E.; Krieger, J.E.; Santos, R.D.; Pereira, A.C. The MYLIP p.N342S polymorphism is associated with response to lipid-lowering therapy in Brazilian patients with familial hypercholesterolemia. Pharm. Genom. 2014, $24,548-555$. [CrossRef] [PubMed]

48. Mabuchi, H.; Nohara, A.; Noguchi, T.; Kobayashi, J.; Kawashiri, M.A.; Inoue, T.; Mori, M.; Tada, H.; Nakanishi, C.; Yagi, K.; et al. Genotypic and phenotypic features in homozygous familial hypercholesterolemia caused by proprotein convertase subtilisin/kexin type 9 (PCSK9) gain-of-function mutation. Atherosclerosis 2014, 236, 54-61. [CrossRef]

49. Leduc, V.; Bourque, L.; Poirier, J.; Dufour, R. Role of rs3846662 and HMGCR alternative splicing in statin efficacy and baseline lipid levels in familial hypercholesterolemia. Pharm. Genom. 2016, 26, 1-11. [CrossRef]

50. Fazio, S.; Robertson, D.G.; Joh, T.; Wan, H.; Riel, T.; Forgues, P.; Baum, C.M.; Garzone, P.D.; Gumbiner, B. Effects of 12 weeks of treatment with intravenously administered bococizumab, a humanized monoclonal antibody blocking proprotein convertase subtilisin/kexin type 9, in hypercholesterolemic subjects on high-dose statin. Cardiovasc Ther. 2018, 36, e12308. [CrossRef] [PubMed]

51. Bea, A.M.; Lamiquiz-Moneo, I.; Marco-Benedi, V.; Mateo-Gallego, R.; Perez-Calahorra, S.; Jarauta, E.; Martin, C.; Cenarro, A.; Civeira, F. Lipid-lowering response in subjects with the p.(Leu167del) mutation in the APOE gene. Atherosclerosis 2019, 282, 143-147. [CrossRef] [PubMed]

52. Dagli-Hernandez, C.; de Freitas, R.C.C.; Marcal, E.; Goncalves, R.M.; Faludi, A.A.; Borges, J.B.; Bastos, G.M.; Los, B.; Mori, A.A.; Bortolin, R.H.; et al. Late response to rosuvastatin and statin-related myalgia due to SLCO1B1, SLCO1B3, ABCB11, and CYP3A5 variants in a patient with Familial Hypercholesterolemia: A case report. Ann. Transl. Med. 2021, 9, 76. [CrossRef]

53. Charland, S.L.; Agatep, B.C.; Herrera, V.; Schrader, B.; Frueh, F.W.; Ryvkin, M.; Shabbeer, J.; Devlin, J.J.; Superko, H.R.; Stanek, E.J. Providing patients with pharmacogenetic test results affects adherence to statin therapy: Results of the Additional KIF6 Risk Offers Better Adherence to Statins (AKROBATS) trial. Pharm. J. 2014, 14, 272-280. [CrossRef]

54. Paquette, M.; Bernard, S.; Thanassoulis, G.; Baass, A. LPA genotype is associated with premature cardiovascular disease in familial hypercholesterolemia. J. Clin. Lipidol. 2019, 13, 627-633.e1. [CrossRef]

55. Chasman, D.I.; Giulianini, F.; MacFadyen, J.; Barratt, B.J.; Nyberg, F.; Ridker, P.M. Genetic determinants of statin-induced low-density lipoprotein cholesterol reduction: The Justification for the Use of Statins in Prevention: An Intervention Trial Evaluating Rosuvastatin (JUPITER) trial. Circ. Cardiovasc. Genet. 2012, 5, 257-264. [CrossRef]

56. Thompson, J.F.; Hyde, C.L.; Wood, L.S.; Paciga, S.A.; Hinds, D.A.; Cox, D.R.; Hovingh, G.K.; Kastelein, J.J. Comprehensive whole-genome and candidate gene analysis for response to statin therapy in the Treating to New Targets (TNT) cohort. Circ. Cardiovasc. Genet. 2009, 2, 173-181. [CrossRef] [PubMed]

57. de Keyser, C.E.; Becker, M.L.; Hofman, A.; Lous, J.J.; Uitterlinden, A.G.; Visser, L.E.; Stricker, B.H. The rs13064411 polymorphism in the WDR52 gene, associated with PCSK9 levels, modifies statin-induced changes in serum total and LDL cholesterol levels. Pharm. Genom. 2015, 25, 134-142. [CrossRef]

58. To, K.K.; Hu, M.; Tomlinson, B. Expression and activity of ABCG2, but not ABCB1 or OATP1B1, are associated with cholesterol levels: Evidence from in vitro and in vivo experiments. Pharmacogenomics 2014, 15, 1091-1104. [CrossRef]

59. Mladenovska, K.; Grapci, A.D.; Vavlukis, M.; Kapedanovska, A.; Eftimov, A.; Geshkovska, N.M.; Nebija, D.; Dimovski, A.J. Influence of SLCO1B1 polymorphisms on atorvastatin efficacy and safety in Macedonian subjects. Pharmazie 2017, 72, 288-295. [CrossRef]

60. Leon-Cachon, R.B.R.; Bamford, A.D.; Meester, I.; Barrera-Saldana, H.A.; Gomez-Silva, M.; Bustos, M.F.G. The atorvastatin metabolic phenotype shift is influenced by interaction of drug-transporter polymorphisms in Mexican population: Results of a randomized trial. Sci. Rep. 2020, 10, 8900. [CrossRef]

61. Wendt, F.R.; Koller, D.; Pathak, G.A.; Jacoby, D.; Miller, E.J.; Polimanti, R. Biobank Scale Pharmacogenomics Informs the Genetic Underpinnings of Simvastatin Use. Clin. Pharm. Ther. 2021, 110, 777-785. [CrossRef]

62. Berthold, H.K.; Laaksonen, R.; Lehtimaki, T.; Gylling, H.; Krone, W.; Gouni-Berthold, I. SREBP-1c gene polymorphism is associated with increased inhibition of cholesterol-absorption in response to ezetimibe treatment. Exp. Clin. Endocrinol. Diabetes 2008, 116, 262-267. [CrossRef]

63. Ference, B.A.; Majeed, F.; Penumetcha, R.; Flack, J.M.; Brook, R.D. Effect of naturally random allocation to lower low-density lipoprotein cholesterol on the risk of coronary heart disease mediated by polymorphisms in NPC1L1, HMGCR, or both: A 2 x 2 factorial Mendelian randomization study. J. Am. Coll. Cardiol. 2015, 65, 1552-1561. [CrossRef]

64. Nakano, Y.; Komiya, C.; Shimizu, H.; Mishima, H.; Shiba, K.; Tsujimoto, K.; Ikeda, K.; Kashimada, K.; Dateki, S.; Yoshiura, K.I.; et al. A case of ezetimibe-effective hypercholesterolemia with a novel heterozygous variant in ABCG5. Endocr. J. 2020, 67, 1099-1105. [CrossRef]

65. Stein, E.A.; Honarpour, N.; Wasserman, S.M.; Xu, F.; Scott, R.; Raal, F.J. Effect of the proprotein convertase subtilisin/kexin 9 monoclonal antibody, AMG 145, in homozygous familial hypercholesterolemia. Circulation 2013, 128, 2113-2120. [CrossRef]

66. Raal, F.J.; Honarpour, N.; Blom, D.J.; Hovingh, G.K.; Xu, F.; Scott, R.; Wasserman, S.M.; Stein, E.A.; Investigators, T. Inhibition of PCSK9 with evolocumab in homozygous familial hypercholesterolaemia (TESLA Part B): A randomised, double-blind, placebo-controlled trial. Lancet 2015, 385, 341-350. [CrossRef]

67. Robinson, J.G.; Farnier, M.; Krempf, M.; Bergeron, J.; Luc, G.; Averna, M.; Stroes, E.S.; Langslet, G.; Raal, F.J.; El Shahawy, M.; et al. Efficacy and safety of alirocumab in reducing lipids and cardiovascular events. N. Engl. J. Med. 2015, 372, 1489-1499. [CrossRef] 
68. D’Erasmo, L.; Cefalu, A.B.; Noto, D.; Giammanco, A.; Averna, M.; Pintus, P.; Medde, P.; Vigna, G.B.; Sirtori, C.; Calabresi, L.; et al. Efficacy of Lomitapide in the Treatment of Familial Homozygous Hypercholesterolemia: Results of a Real-World Clinical Experience in Italy. Adv. Ther. 2017, 34, 1200-1210. [CrossRef]

69. Andersen, L.; Davis, T.; Testa, H.; Andersen, R.L. PCSK9 inhibitor therapy in homozygous familial defective apolipoprotein B-100 due to APOB R3500Q: A case report. J. Clin. Lipidol. 2017, 11, 1471-1474. [CrossRef]

70. Fahy, E.F.; McCarthy, E.; Steinhagen-Thiessen, E.; Vaughan, C.J. A case of autosomal recessive hypercholesterolemia responsive to proprotein convertase subtilisin/kexin 9 inhibition. J. Clin. Lipidol. 2017, 11, 287-288. [CrossRef]

71. Gaudet, D.; Gipe, D.A.; Pordy, R.; Ahmad, Z.; Cuchel, M.; Shah, P.K.; Chyu, K.Y.; Sasiela, W.J.; Chan, K.C.; Brisson, D.; et al. ANGPTL3 Inhibition in Homozygous Familial Hypercholesterolemia. N. Engl. J. Med. 2017, 377, 296-297. [CrossRef] [PubMed]

72. Doyle, M. Differential Responses to the PCSK9 Inhibitors, Evolocumab and Alirocumab, in a Patient with Heterozygous Familial Hypercholesterolemia: A Case Report. Clin. Lipidol. 2018, 12, 558-559. [CrossRef]

73. Real, J.; Arbona, C.; Goterris, R.; Ascaso, J.F. Management of homozygous familial hypercholesterolaemia in two brothers. BMJ Case Rep. 2018, 2018, bcr-2017. [CrossRef]

74. Rodriguez-Jimenez, C.; Gomez-Coronado, D.; Frias Vargas, M.; Cerrato, F.; Lahoz, C.; Saban-Ruiz, J.; Gonzalez-Nieto, D.; Lasuncion, M.A.; Mostaza, J.M.; Rodriguez-Novoa, S. A new variant (c.1A>G) in LDLRAP1 causing autosomal recessive hypercholesterolemia: Characterization of the defect and response to PCSK9 inhibition. Atherosclerosis 2019, 284, $223-229$. [CrossRef]

75. Banerjee, P.; Chan, K.C.; Tarabocchia, M.; Benito-Vicente, A.; Alves, A.C.; Uribe, K.B.; Bourbon, M.; Skiba, P.J.; Pordy, R.; Gipe, D.A.; et al. Functional Analysis of LDLR (Low-Density Lipoprotein Receptor) Variants in Patient Lymphocytes to Assess the Effect of Evinacumab in Homozygous Familial Hypercholesterolemia Patients With a Spectrum of LDLR Activity. Arter. Thromb. Vasc. Biol. 2019, 39, 2248-2260. [CrossRef] [PubMed]

76. Bayona, A.; Arrieta, F.; Rodriguez-Jimenez, C.; Cerrato, F.; Rodriguez-Novoa, S.; Fernandez-Lucas, M.; Gomez-Coronado, D.; Mata, P. Loss-of-function mutation of PCSK9 as a protective factor in the clinical expression of familial hypercholesterolemia: A case report. Medicine 2020, 99, e21754. [CrossRef]

77. Velvet, A.J.J.; Soran, H.; Clarke, B.; Motwani, M.; Ordoubadi, F.F.; Daniels, M.J. Homozygous familial hypercholesterolemia with an update on cholesterol management. Oxf. Med. Case Rep. 2020, 2020, omaa072. [CrossRef]

78. Blom, D.J.; Harada-Shiba, M.; Rubba, P.; Gaudet, D.; Kastelein, J.J.P.; Charng, M.J.; Pordy, R.; Donahue, S.; Ali, S.; Dong, Y.; et al. Efficacy and Safety of Alirocumab in Adults With Homozygous Familial Hypercholesterolemia: The ODYSSEY HoFH Trial. J. Am. Coll. Cardiol. 2020, 76, 131-142. [CrossRef] [PubMed]

79. Mahzari, M.; Zarif, H. Homozygous Familial Hypercholesterolemia (HoFH) in Saudi Arabia and Two Cases of Lomitapide Use in a Real-World Setting. Adv. Ther. 2021, 38, 2159-2169. [CrossRef]

80. Kastelein, J.J.; Besseling, J.; Shah, S.; Bergeron, J.; Langslet, G.; Hovingh, G.K.; Al-Saady, N.; Koeijvoets, M.; Hunter, J.; Johnson-Levonas, A.O; ; et al. Anacetrapib as lipid-modifying therapy in patients with heterozygous familial hypercholesterolaemia (REALIZE): A randomised, double-blind, placebo-controlled, phase 3 study. Lancet 2015, 385, 2153-2161. [CrossRef]

81. Gaudet, D.; Durst, R.; Lepor, N.; Bakker-Arkema, R.; Bisgaier, C.; Masson, L.; Golden, L.; Kastelein, J.J.; Hegele, R.A.; Stein, E. Usefulness of Gemcabene in Homozygous Familial Hypercholesterolemia (from COBALT-1). Am. J. Cardiol. 2019, 124, $1876-1880$. [CrossRef]

82. Raal, F.J.; Kallend, D.; Ray, K.K.; Turner, T.; Koenig, W.; Wright, R.S.; Wijngaard, P.L.J.; Curcio, D.; Jaros, M.J.; Leiter, L.A.; et al. Inclisiran for the Treatment of Heterozygous Familial Hypercholesterolemia. N. Engl. J. Med. 2020, 382, 1520-1530. [CrossRef]

83. Brandts, J.; Dharmayat, K.I.; Vallejo-Vaz, A.J.; Azar Sharabiani, M.T.; Jones, R.; Kastelein, J.J.P.; Raal, F.J.; Ray, K.K. A meta-analysis of medications directed against PCSK9 in familial hypercholesterolemia. Atherosclerosis 2021, 325, 46-56. [CrossRef]

84. Naoumova, R.P.; Tosi, I.; Patel, D.; Neuwirth, C.; Horswell, S.D.; Marais, A.D.; van Heyningen, C.; Soutar, A.K. Severe hypercholesterolemia in four British families with the D374Y mutation in the PCSK9 gene: Long-term follow-up and treatment response. Arter. Thromb. Vasc. Biol. 2005, 25, 2654-2660. [CrossRef]

85. Hopkins, P.N.; Krempf, M.; Bruckert, E.; Donahue, S.; Yang, F.; Zhang, Y.; DiCioccio, A.T. Pharmacokinetic and pharmacodynamic assessment of alirocumab in patients with familial hypercholesterolemia associated with proprotein convertase subtilisin/kexin type 9 gain-of-function or apolipoprotein B loss-of-function mutations. J. Clin. Lipidol. 2019, 13, 970-978. [CrossRef]

86. Reeskamp, L.F.; Kastelein, J.J.P.; Moriarty, P.M.; Duell, P.B.; Catapano, A.L.; Santos, R.D.; Ballantyne, C.M. Safety and efficacy of mipomersen in patients with heterozygous familial hypercholesterolemia. Atherosclerosis 2019, 280, 109-117. [CrossRef]

87. Raal, F.J.; Braamskamp, M.J.; Selvey, S.L.; Sensinger, C.H.; Kastelein, J.J. Pediatric experience with mipomersen as adjunctive therapy for homozygous familial hypercholesterolemia. J. Clin. Lipidol. 2016, 10, 860-869. [CrossRef]

88. Bjorn, L.; Leren, T.P.; Ose, L.; Hamsten, A.; Karpe, F. A functional polymorphism in the promoter region of the microsomal triglyceride transfer protein (MTP $-493 \mathrm{G} / \mathrm{T}$ ) influences lipoprotein phenotype in familial hypercholesterolemia. Arter. Thromb. Vasc. Biol. 2000, 20, 1784-1788. [CrossRef]

89. Wang, L.; Muthuramu, I.; Somanathan, S.; Zhang, H.; Bell, P.; He, Z.; Yu, H.; Zhu, Y.; Tretiakova, A.P.; Wilson, J.M. Developing a second-generation clinical candidate AAV vector for gene therapy of familial hypercholesterolemia. Mol. Ther. Methods Clin. Dev. 2021, 22, 1-10. [CrossRef] [PubMed] 
90. Kuehn, B.M. Evinacumab Approval Adds a New Option for Homozygous Familial Hypercholesterolemia with a Hefty Price Tag. Circulation 2021, 143, 2494-2496. [CrossRef] [PubMed]

91. Rubino, J.; MacDougall, D.E.; Sterling, L.R.; Hanselman, J.C.; Nicholls, S.J. Combination of bempedoic acid, ezetimibe, and atorvastatin in patients with hypercholesterolemia: A randomized clinical trial. Atherosclerosis 2021, 320, 122-128. [CrossRef] [PubMed]

92. Arai, H.; Teramoto, T.; Daida, H.; Ikewaki, K.; Maeda, Y.; Nakagomi, M.; Shirakawa, M.; Kakikawa, T.; Numaguchi, H.; Johnson-Levonas, A.O.; et al. Efficacy and safety of the cholesteryl ester transfer protein inhibitor anacetrapib in Japanese patients with heterozygous familial hypercholesterolemia. Atherosclerosis 2016, 249, 215-223. [CrossRef] 